\title{
LiFE AMONG THE RUINS: \\ SECTION 91(24) AFTER \\ TSILHQOT'IN AND GRASSY NARROWS
}

\author{
KERRY WILKINS*
}

\begin{abstract}
In two landmark 2014 decisions - Tsilhqot'in and Grassy Narrows — the Supreme Court of Canada held that section 35 of the Constitution Act, 1982, is all that protects existing Aboriginal and treaty rights from federal or provincial infringement: that such rights derive no additional protection from the doctrine of interjurisdictional immunity. This article examines that conclusion by criticizing the reasoning offered in its support, pointing out its unacknowledged doctrinal implications, and inviting a broader conversation about how the law should address them.
\end{abstract}

\section{TABLE OF CONTENTS}

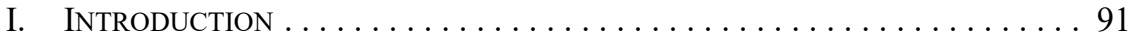

II. Some Fundamentals AND SOME History $\ldots \ldots \ldots \ldots \ldots \ldots \ldots \ldots . \ldots 94$

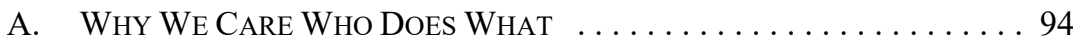

B. Section 91(24) and Its Provenance $\ldots \ldots \ldots \ldots \ldots \ldots \ldots . \ldots 9$

C. InTERJURISDICTIONAL IMMUNITY IN A NUTSHELL . . . . . . . . . . 98

D. The DAy Before TSILHQOT'IN $\ldots \ldots \ldots \ldots \ldots \ldots \ldots \ldots \ldots$

III. TSILHQOT'IN, SECTION 35 RIGHTS, AND INTERJURISDICTIONAL IMMUNITY $\ldots \ldots \ldots \ldots \ldots \ldots \ldots \ldots \ldots \ldots \ldots \ldots \ldots \ldots$

A. Double ASPECt? CONCURRENT JURISDICTION? . . . . . . . . . 103

B. SECTION 35 AND INTERJURISDICTIONAL IMMUNITY:

THE PREVIOUS JuRisPRUdENCE . . . . . . . . . . . . . . . . . . 104

C. Rights Against Government: The Charter Analogy . . . . . . 107

D. Of Dueling Tests and Practical Difficulties $\ldots \ldots \ldots \ldots 110$

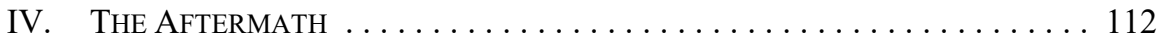

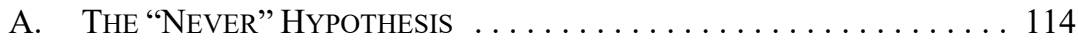

B. THE Eviction Hypothesis $\ldots \ldots \ldots \ldots \ldots \ldots \ldots \ldots \ldots \ldots \ldots \ldots \ldots$

C. EITHER WAY . . . . . . . . . . . . . . . . . . . . . . . 119

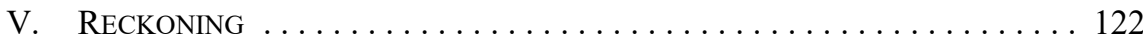

\section{INTRODUCTION}

In Tsilhqot'in Nation v. British Columbia, ${ }^{1}$ the first of the two landmark Supreme Court of Canada decisions on Aboriginal law in 2014, the Supreme Court worked hard to conclude, for the first time, that an Indigenous community has Aboriginal title to a defined portion of the territory it has occupied traditionally. ${ }^{2}$ In the second of these decisions, Grassy Narrows First Nation v. Ontario (Natural Resources), ${ }^{3}$ decided two weeks later, the Supreme Court worked equally hard to conclude, despite the "Dominion of Canada" language explicit in

Adjunct Professor, Faculty of Law, University of Toronto. Sincere thanks to Kent McNeil, Carol Rogerson, Ashley McKenzie, Dana McLean, Diane McMurray, and Constance Marlatt for perceptive comments on earlier drafts. Remaining missteps are my fault, not theirs.

2014 SCC 44, [2014] 2 SCR 257 [Tsilhqot'in].

Ibid at paras 51-66.

2014 SCC 48, [2014] 2 SCR 447 [Grassy Narrows]. 
Treaty $3,{ }^{4}$ that the government of Ontario may take up surrendered Treaty 3 lands without necessarily infringing the treaty harvesting rights that any such taking up would displace. ${ }^{5}$

Tsilhqot'in was a significant win for Indigenous peoples — Grassy Narrows, a significant loss. Despite this, and despite the remarkable differences in orientation between these two decisions, they did agree on one key conclusion. Both held, in no uncertain terms, that neither existing Aboriginal nor existing treaty rights derive any protection from the constitutional doctrine of interjurisdictional immunity (IJI), and that section 35 of the Constitution Act, $1982^{6}$ is the sole and sufficient source of protection available to such rights against provincial, as well as federal, infringement. That conclusion is the focus of this article.

It was, to begin with, a conclusion the Supreme Court chose consciously to reach on an issue that neither proceeding required it to address. Having concluded that the appellants have Aboriginal title to the relevant lands and that the Crown had failed to fulfill its duty to consult about its forest planning in respect of those lands, the Supreme Court had done all it had to do to dispose of the Tsilhqot'in appeal. ${ }^{7}$ Having then gone on to conclude that the British Columbia Forest $\mathrm{Act}^{8}$ does not, as drafted, purport to apply to lands declared to be subject to Aboriginal title, ${ }^{9}$ the Supreme Court had additional warrant to defer consideration of the division of powers issue until confronted with a provincial law that did purport to apply to the relevant lands. Likewise, having concluded that Ontario could take up surrendered Treaty 3 lands without routinely infringing the harvesting rights protected in that treaty, the Supreme Court in Grassy Narrows had no need, as it itself acknowledged, ${ }^{10}$ to consider whether, and if so, when and how, a province could infringe Indigenous peoples' treaty rights. In some sense, the Supreme Court used these decisions to discuss and dismiss IJI because it wanted to. That fact itself is worthy of our interest.

Treaty 3 between Her Majesty the Queen and the Saulteaux Tribe of the Ojibbeway Indians at the Northwest Angle on the Lake of the Woods with Adhesions, 3 October 1873, online: <www.aadncaandc.gc.ca/eng/1100100028675/1100100028679>. Here is the relevant treaty text:

Her Majesty further agrees with Her said Indians that they, the said Indians, shall have [the] right to pursue their avocations of hunting and fishing throughout the tract surrendered as hereinbefore described, subject to such regulations as may from time to time be made by Her Government of Her Dominion of Canada, and saving and excepting such tracts as may, from time to time, be required or taken up for settlement, mining, lumbering or other purposes by Her said Government of the Dominion of Canada, or by any of the subjects thereof duly authorized therefor by the said Government.

In truth, this description oversimplifies somewhat. The only Treaty 3 lands at issue in Grassy Narrows, supra note 3 were the so-called Keewatin lands - those lands within the Treaty 3 area that were federal Crown lands at the time of the treaty (1873) but became part of Ontario as a result of the reciprocal boundary extension legislation in 1912 (The Ontario Boundaries Extension Act, SC 1912, c 40; The Ontario Boundaries Extension Act, SO 1912, c 3). For purposes of this litigation, the plaintiffs had accepted that Ontario had and retained the power to take up surrendered Treaty 3 lands that lay within its pre-1912 boundaries.

$6 \quad$ Being Schedule B to the Canada Act 1982 (UK), 1982, c 11.

7 Tsilhqot'in, supra note 1 at para 98 . It is, perhaps, significant that it was British Columbia, not the appellant Tsilhqot'in Nation, that had asked the Supreme Court to state the constitutional questions concerning provincial capacity to infringe Aboriginal title. See online: <www.scc-csc.ca/casedossier/info/dock-regi-eng.aspx ?cas $=34986>$ (motion filed on 22 February 2013).

RSBC 1996, c 157.

Tsilhqot'in, supra note 1 at paras 107-16.

See Grassy Narrows, supra note 3 at para 53. 
Apart from that, there is nothing too surprising about the Supreme Court's treatment of IJI in these two decisions. Since Canadian Western Bank v. Alberta, ${ }^{11}$ released in 2007, the Supreme Court has consistently expressed displeasure with IJI, ${ }^{12}$ taking pains, even in the two decisions in which it invoked IJI, ${ }^{13}$ to constrict the doctrinal space available to it. Its discussion of IJI in Tsilhqot'in and Grassy Narrows is, in tone, quite in keeping with that generic discomfort. But more importantly, the Supreme Court's conclusion has a certain appeal from the standpoint of constitutional pragmatics. The effect of using IJI to protect existing treaty and Aboriginal rights from provincial activity would be to deprive the provinces of any independent capacity to "impair" through regulatory measures such rights or their exercise. Enforcing such a deprivation, especially where the putative provincial restrictions seemed otherwise entirely justifiable, would make treaty and Aboriginal rights at once inconvenient and extremely expensive in the coinage of constitutional law and argument. Raising the stakes to that extent in treaty and Aboriginal rights litigation could well discourage courts from accrediting any but the most harmless and obvious Aboriginal rights, and from maintaining generous, flexible rules of treaty interpretation. ${ }^{14}$ Section 35 , on the other hand, has been held to countenance justified infringement of such rights. ${ }^{15}$ By adopting section 35 as the only source of constitutional protection available to treaty and Aboriginal rights, the Supreme Court has helped make the world safer for them (or, perhaps, vice versa).

As attractive as this outcome seems, it deserves our careful scrutiny, for the reasoning used to achieve it risks destabilizing a good deal of related constitutional doctrine. Much of what we thought we knew about the Constitution, the division of powers, and Indigenous peoples and their rights is now open to doubt. Nothing in either Tsilhqot'in or Grassy Narrows suggests that the Supreme Court took notice of the doctrinal risks it was courting:

112007 SCC 22, [2007] 2 SCR 3 [Canadian Western Bank].

12 See British Columbia (Attorney General) v Lafarge Canada Inc, 2007 SCC 23, [2007] 2 SCR 86 [Lafarge], released concurrently with Canadian Western Bank, ibid; Canada (Attorney General) v PHS Community Services Society, 2011 SCC 44, [2011] 3 SCR 134 [PHS]; Marine Services International Ltd v Ryan Estate, 2013 SCC 44, [2013] 3 SCR 53 [Ryan Estate]; Bank of Montreal v Marcotte, 2014 SCC 55, [2014] 2 SCR 725 [Marcotte].

13 Quebec (Attorney General) v Canadian Owners and Pilots Association, 2010 SCC 39, [2010] 2 SCR 536 [COPA]; Rogers Communications Inc v Châteauguay (City), 2016 SCC 23, [2016] 1 SCR 467 [Rogers].

14 Ian Binnie, writing in 1990 (before his appointment to the Supreme Court) about the consequences of the decision in $R$ v Sparrow, [1990] 1 SCR 1075 [Sparrow], made a very similar point in "The Sparrow Doctrine: Beginning of the End or End of the Beginning?" (1990) 15:2 Queen's LJ 217 at 218 [footnote omitted]:

It was inevitable that there would be a trade off between the scope of the rights and the strength of their constitutional protection against encroachment. The checks and balances of the Constitution ... do not favour both a "liberal and generous" reading of the rights and a high level of immunity. The Supreme Court attaches great importance to flexibility in a constitutional document to meet changing conditions. Having erected something of a legal fortress around section 35 rights, it will now be cautious and somewhat circumspect in identifying the specific activities that belong within the fortress.

Binnie's concern was about the high standard the Supreme Court had imposed in Sparrow for justification of Aboriginal rights infringements. His concern would arise a fortiori if provinces were deprived altogether of capacity to justify infringements of such rights.

15 See e.g. Sparrow, ibid at 1109-10, 1113-19; $R$ v Gladstone, [1996] 2 SCR 723 at paras 54-82 [Gladstone] (Aboriginal rights); Delgamuukw v British Columbia, [1997] 3 SCR 1010 at paras 160-69 [Delgamuukw]; Tsilhqot'in, supra note 1 at paras 77-88 (Aboriginal title); $R v$ Badger, [1996] 1 SCR 771 at paras 86-98 (treaty rights). The requirements the Court set out for justification in Tsilhqot'in, ibid, appear to make the task of justifying infringements of such rights more difficult than it would have been under some earlier formulations of the test. 
of the magnitude of the disruption its approach on this issue entails. It seems prudent to document the damage and to begin to reflect upon our options in its wake.

The discussion to follow has four remaining parts: (1) a brief primer on the division of powers, section 91(24) of the Constitution Act, 1867, ${ }^{16}$ and what we thought we knew about IJI the day before Tsilhqot'in; (2) a detailed analysis of the Court's reasons for denying IJI protection to existing treaty and Aboriginal rights; (3) an account of the resulting doctrinal disarray; and (4) a final reckoning.

\section{SOME Fundamentals AND SOME HiSTORY}

\section{A. Why We Care Who Does What}

"It is undisputed," the Supreme Court has told us, "that Canada is a federal state." 17 The Quebec Secession Reference listed federalism first among the "four foundational constitutional principles" 18 that comprise "the vital unstated assumptions upon which the text [of Canada's Constitution] is based."19

It would make no sense to create a federal, instead of a unitary, state, however, if each order of government could do just whatever it wanted. The whole point of a federation is to distribute in some rational manner the corpus of mainstream authority among the constituent orders of government such that each has different powers. In Canada, each order of government, the federal and the provincial, has a catalogue of subjects about which only it may make laws. The Supreme Court has assured us that this distribution is rational and appropriate. The Constitution, it has said, "assign[s] each power to the level of government best suited to exercise it.... Broad powers were given to the provincial legislatures with respect to local matters, in recognition of regional diversity, while powers relating to matters of national importance were given to Parliament, to ensure unity."20 "Each head of power," the Supreme Court has said, "was assigned to the level of government best placed to exercise the power." ${ }^{21}$ Having different constitutional mandates, our two orders of government necessarily have different expertise and different geographical and policy orientations. It would be most peculiar if they did not.

From this, it follows, however, that ensuring that each order of government sticks to its own proper business is of considerable independent significance within our constitutional order. It is true that certain other constitutional constraints beset both orders of government: neither may infringe unjustifiably on Indigenous peoples' existing treaty or Aboriginal rights $^{22}$ or the rights enumerated in the Canadian Charter of Rights and Freedoms, ${ }^{23}$ and

(UK), 30 \& 31 Vict, c 3, reprinted in RSC 1985, Appendix II, No 5.

Reference re Secession of Quebec, [1998] 2 SCR 217 at para 55 [Quebec Secession Reference]. Ibid at para 49 .

Ibid.

Alberta (Attorney General) v Moloney, 2015 SCC 51, [2015] 3 SCR 327 at para 14 [citation omitted] [Moloney].

Canadian Western Bank, supra note 11 at para 22.

Constitution Act, 1982, supra note 6, s 35.

Part I of the Constitution Act, 1982, being Schedule B to the Canada Act 1982 (UK), 1982, c 11 [Charter]. 
neither may disturb a guaranteed core of superior court jurisdiction. ${ }^{24}$ But the existence of these other constraints, which serve quite different purposes, does not diminish the ongoing importance of confining the work of the federal order to properly federal matters, and that of the provincial order to matters reserved to the provinces. The Supreme Court has long recognized that the "distribution of powers provisions contained in the Constitution Act, 1867 ... set boundaries that are of interest to, and can be relied upon by, all Canadians," 25 and that:

The country is entitled to insist that legislation adopted under section 91 [of the Constitution Act, 1867] should be passed exclusively by the Parliament of Canada in the same way as the people of each Province are entitled to insist that legislation concerning the matters enumerated in section 92 should come exclusively from their respective Legislatures. ${ }^{26}$

It is for this reason that legislation, even today, has no force or effect when courts conclude that it really concerns a matter that lies within the exclusive purview of the other order of government. Each of us has the capacity and the right, without preconditions, to invoke constitutional discipline when we have reason to believe that either order of government is exceeding its legislative authority. ${ }^{27}$

\section{B. Section 91(24) and Its Provenance}

Our interest here is in section 91(24) of the Constitution Act, 1867. Section 91(24) reserves to the federal order exclusive authority to make laws in relation to "Indians, and Lands reserved for the Indians." "It appears to be the plain policy of the [1867] Act," the Privy Council said in 1888, "that, in order to ensure uniformity of administration, all [lands reserved, upon any terms or conditions, for Indian occupation], and Indian affairs generally, shall be under the legislative control of one central authority." 29 As a result, there are certain things about Indians and Indian lands - quite a number, potentially — that only the federal order of government may address or achieve. Provincial laws found to be really about either Indians or their lands are, for that reason, going to be invalid. But why would those responsible for the original Constitution have reserved those classes of subjects expressly to federal legislative administration? MacMillan Bloedel Ltd v Simpson, [1995] 4 SCR 725.

Kitkatla Band v British Columbia (Minister of Small Business, Tourism and Culture), 2002 SCC 31, [2002] 2 SCR 146 at para 72 [Kitkatla], quoting with approval OPSEU v Ontario (Attorney General), [1987] 2 SCR 2 at 19, Dickson CJC.

26 Nova Scotia (AG) v Canada (AG) (1950), [1951] SCR 31 at 34, Rinfret CJC [Nova Scotia Interdelegation].

See e.g. Thorson v Canada (AG), [1975] 1 SCR 138 at 151-52.

Constitution Act, 1867, supra note 16, s 91(24).

St Catherine's Milling and Lumber Co v R, [1888] UKPC 70, 14 AC 46 at 59 [St Catherine's Milling]. 
As courts ${ }^{30}$ and commentators ${ }^{31}$ have noted, nowhere in the recorded debates that led to Confederation is there any mention of Indians or their lands. I, too, found none. This could mean either that section 91(24) was an afterthought, or that it was so obvious to everyone at the time that "Indians" and their lands were of national importance that the issue really needed no discussion.

From all indications, the latter view is the better one. ${ }^{32}$ For one thing, it is clear that the framers' decision to reserve "Indians, and Lands reserved for the Indians" to the federal order was deliberate. By 1860, Nova Scotia, ${ }^{33}$ New Brunswick, ${ }^{34}$ and the pre-Confederation Province of Canada ${ }^{35}$ had all assumed local authority over Indians and their lands. ${ }^{36}$ Provincial jurisdiction was the default arrangement in the years just before Confederation; the framers of the 1867 Constitution had, at the time of their deliberations, at least some experience with it. Had they omitted section 91(24), this trend would have continued. ${ }^{37}$ Section 91(24) bespoke a conscious decision to substitute federal administration.

The interesting question is, again, why? In his classic 1969 article on the division of powers, Albert Abel identified sections 91(24) and 91(25) ${ }^{38}$ as federal powers involving "relations with persons outside the political community, to which a common attitude and a central direction are presuppositions of even loosely knit alliances." 39 Beyond that, there appear to be two competing explanations. In Daniels, the Supreme Court linked section

See e.g. Daniels v Canada (Indian Affairs and Northern Development), 2013 FC 6, [2013] 2 FCR 268 at para 336 [Daniels FC], aff'd in part 2014 FCA 101, [2014] 4 FCR 97, aff'd in part 2016 SCC 12, [2016] 1 SCR 99 [Daniels]:

A startling feature of the "Indian power" is that there was no discussion of the power, of the need to control Indians or of what constituted Indians. In the period from 1858 to 1867, when there is a record of discussions by delegates to the Confederation Conference about the range of topics from political deadlock, to education, religion, local autonomy, fear of U.S. annexation and expansion into the north-west (northern Ontario to Alberta), there is not one reference to "Indians" or the issue of what level of government should be responsible or who was to be included in this power.

31 See e.g. Douglas Sanders, "Prior Claims: Aboriginal People in the Constitution of Canada" in Stanley M Beck \& Ivan Bernier, eds, Canada and the New Constitution: The Unfinished Agenda, vol 1 (Montreal: Institute for Research on Public Policy, 1983) 225 (" $[\mathrm{t}]$ here are no records of discussions on the decision in favour of central authority [over Indians and Indian lands] in Canada in 1867" at 273, n 23).

32 Daniels FC, supra note 30 at paras 337-38:

Unlike so much of federal-provincial relations, the power over Indians was not one that was fought over or bargained over between governments. That was the case in 1864 and is the case now. This has led to the conclusion that the Indian power was not an important power, critical to the purposes of Confederation. That conclusion is countered by the proposition that given the purposes of Confederation, the power over Indians was so clearly necessary for the federal government that there was no need for discussion. Given the history of Confederation and subsequent events, this latter conclusion is the more reasonable one particularly given the legal requirement to look at the purposes of legislation in construing its provisions. An Act to provide for the Instruction and Permanent Settlement of the Indians, SNS 1842 (5 Vict), c 16; An Act concerning Indian Reserves, SNS 1859 (22 Vict), c 14.

An Act to regulate the management and disposal of the Indian Reserves in this Province, SNB 1844 (7 Vict), c 47; Of Indian Reserves, SNB 1854 (17 Vict), c 85.

35 An Act respecting Indians and Indian Lands, S Prov C 1860 (23 Vict), c 14; An Act respecting the Management of the Indian Lands and Property, S Prov C 1860 (23 Vict), c 151. See generally PG McHugh, Aboriginal Societies and the Common Law: A History of Sovereignty, Status, and Self-Determination (Oxford: Oxford University Press, 2004) at 182-83. Thanks to Diane McMurray for calling this to my attention.

37 Sanders, supra note 31. According to Sanders, "[p]rovincial jurisdiction [over Indians and their lands] would have been logical" both because "[b]y 1867 significantly different legal patterns had developed in the colonies that federated" and because "the provinces were given jurisdiction over land, education, and social welfare matters, all relevant to Indian questions" (ibid at 273-74, n 23). 
91(24) to the project of expanding European settlement westward and northward and to the construction of a national railway. "With jurisdiction over Aboriginal peoples," the Supreme Court observed, "the new federal government could "protect the railway from attack' and ensure that they did not resist settlement or interfere with construction of the railway. $" 41$ Though the Supreme Court does not say so, one potential consequence of this approach — today, with the railway network complete and the west and north fairly teeming with non-Indigenous settlers — is that federal authority over Indigenous peoples and their lands is no longer necessary or especially useful.

I confess that I find this explanation unconvincing, ${ }^{42}$ for a couple of reasons. First, the Constitution also assigns to the federal order exclusive authority to provide for an interprovincial railway ${ }^{43}$ and for "Militia, Military and Naval Service, and Defence." ${ }^{44}$ If the only purpose of section 91(24) was to protect the railway and the settlers from hostilities, these other heads of federal power would probably have sufficed. But second, in the territories earmarked for railways and settlement, there were no provincial legislatures or governments to assert competing authority. While those lands remained territories, the federal order of government, for the purposes of Canadian law, was the only game in town. At those times in those areas, it would not have needed section 91(24) to empower its dealings with Indigenous peoples.

The alternative foundation, which I find more convincing, ${ }^{45}$ draws upon the conclusion, articulated in both an 1837 report of a British Select Committee ${ }^{46}$ and an 1847 Report of the Province of Canada, ${ }^{47}$ that Indians and their lands required the protection of a centralized authority from the adverse interests of local settlers. "To the extent that there was, indeed,

Daniels, supra note 30 at para 25.

Ibid.

So, several decades earlier, did Douglas Sanders. See Sanders, supra note 31 at 273-74, n 23.

Constitution Act, 1867, supra note 16, ss 91(29), 92(10)(a).

Ibid, s 91(7).

See also Bruce McIvor \& Kate Gunn, "Stepping Into Canada’s Shoes: Tsilhqot'in, Grassy Narrows and the Division of Powers" (2016) 67 UNBLJ 146 at 147-49, 158-59.

46 UK, HC, "Report of the Parliamentary Select Committee on Aboriginal Tribes (British Settlements)" (1837) [1837 Report].

47 Legislative Assembly, Journals of the Legislative Assembly of the Province of Canada, 2nd Parl, 3rd Sess, vol 6, no 1 (1847), Appendix T [1847 Report].

48 Ibid. The first General Recommendation in the Report urged: "[A]s long as the Indian Tribes continue to require the special protection and guidance of the Government, they should remain under the immediate control of the Representative of the Crown within the Province, and not under that of the Provincial Authorities." In support, it quoted with approval this passage from the 1837 Report, supra note 46:

The protection of the Aborigines should be considered as a duty peculiarly belonging and appropriate to the Executive Government, as administered either in this country or by the Governors of the respective Colonies. This is not a trust which could conveniently be confided to the local Legislatures. In proportion as those bodies are qualified for the right discharge of their proper functions, they will be unfit for the performance of this office, for a local Legislature, if properly constituted, should partake largely in the interests, and represent the feelings of the settled opinions of the great mass of the people for whom they act. But the settlers in almost every Colony, having either, disputes to adjust with the native Tribes, or claims to urge against them, the Representative body is virtually a party, and, therefore, ought not to be the judge in such controversies; or, if the Members of the Colonial Legislature are not chosen by the people, but selected by the Government, there is still a similar objection to their interference with regard to the Aborigines. Possessing an invidious elevation, in which they are supported by no other title than that of the preference of the Crown, they will endeavor to abate the ill-will which follows on such superiority, by ministering to all popular prejudices which do not directly invade the power and the rights of the Government they serve. Whatever may be the Legislative system of any Colony, we therefore advise, that, as far as possible, the Aborigines be withdrawn from its control. 
a theory or principle behind the decision in favour of centralized authority" in 1867, Sanders concludes,

that theory would have embodied the idea that the more distant level of government would better protect Indians against the interests of local settlers. While Indians were commonly seen as 'problems', they were understood by political leaders to be the victims of colonial expansion. The idea of their need for protection was well established. ${ }^{49}$

Peter Hogg, citing Sanders with approval, agrees that this was the "main reason for s. $91(24), " 50$ adding that "[a] second reason was probably the desire to maintain uniform national policies respecting the Indians." $" 51$

On this latter account, section 91(24) is a deliberate exception to the principle of subsidiarity, on which the Supreme Court relied in part in its critique of IJI in Canadian Western Bank. ${ }^{52}$

\section{INTERJURISDICTIONAL IMMUNITY IN A NUTSHELL}

When legislative authority is exclusive, part of what that means is that the order of government to which it belongs is the only one with permission to decide when and how it ought to be exercised. Non-use by one order of government of its legislative authority does not entitle the other to take up what it perceives to be the slack. ${ }^{53}$ Validity analysis - the socalled pith and substance doctrine - protects each order of government from attempts by the other to achieve results that only it is permitted to seek to achieve. Put differently, it protects exclusive legislative authority from the advertent effects of invalid legislation. It does so regardless of whether the empowered order of government has any interest in achieving the authority-encroaching results.

$49 \quad$ Sanders, supra note 31 at 238.

50 Peter W Hogg, Constitutional Law of Canada (Toronto: Carswell, 2015) (loose-leaf 2015 supplement), ch 28 at 2 .

Ibid.

Supra note 11 at para 45. Subsidiarity is the notion, quite plausible in other contexts, that "decisions 'are often best [made] at a level of government that is not only effective, but also closest to the citizens affected"' (ibid, quoting with approval 114957 Canada Ltée (Spraytech, Société d'arrosage) v Hudson (Town), 2001 SCC 40, [2001] 2 SCR 241 at para 3).

53 Union Colliery Co of British Columbia v Bryden, [1899] UKPC 58, [1899] AC 580 [Union Colliery] ("[t]he abstinence of the Dominion Parliament from legislating to the full limit of its powers, could not have the effect of transferring to any provincial legislature the legislative power which had been assigned to the Dominion by s. 91 of the Act of 1867" at 588). 
IJI provides exclusive federal ${ }^{54}$ legislative authority with equivalent protection against the inadvertent effects of valid provincial legislation. It operates in instances where provincial legislation, despite being enacted for an appropriately provincial purpose, has effects on exclusively federal matters that only the federal order has constitutional authority to achieve. In concluding that the legislation is valid nonetheless, the court is accepting that the province did not intend these effects; had the province sought to achieve them, the legislation would be invalid. To preserve the statute's validity, the court reads it down, immunizing from its application matters within exclusive federal legislative authority, while leaving it intact throughout the range to which it validly applies. Again, it makes no difference whether there is any relevant federal legislation.

Why do this? Because, as the Supreme Court said unanimously in Bell Canada v. Quebec (Commission de la santé et de la sécurité du travail), "[t]he rule of the exclusive nature of fields of jurisdiction does not depend on a legislative drafting technique."55 In a useful 2008 article, Robin Elliot put it in this way:

\begin{abstract}
A provincial legislature that decides to enact a generally worded — and, we can assume for present purposes, perfectly valid - statute that the provincial government subsequently seeks to apply in a context that arguably falls within the exclusive jurisdiction of Parliament should be neither worse nor better off than a provincial legislature that specifies, in a long list of contexts within which its virtually identical statute is to apply, that very same arguably federal context. ${ }^{56}$
\end{abstract}

By ensuring the exclusivity of exclusive federal authority, IJI also operates to preserve "Parliament's legislative freedom," ${ }^{57}$ in respect of matters within that core of exclusive authority, to "introduce broad, permissive legislation, should it so choose" insufficient, on paramountcy grounds, to oust unwelcome but valid provincial statutory restrictions ${ }^{59}$ — or even to elect to leave some such matters altogether unregulated, governed only by private ordering, the common law, or customary Indigenous law. But for IJI, the federal order would have little, if any, capacity to do so.

Despite earlier authority to the contrary (see e.g. Friends of the Oldman River Society $v$ Canada (Minister of Transport), [1992] 1 SCR 3 at 68; Alberta Government Telephones $v$ Canada (Canadian Radio-Television and Telecommunications Commission), [1989] 2 SCR 225 at 275), the Supreme Court has recently suggested on several occasions that IJI can also protect exclusive provincial authority from impairment resulting from valid federal legislation (see e.g. Canadian Western Bank, supra note 11 at para 35; PHS, supra note 12 at para 65; Tsilhqot'in, supra note 1 at paras 131,148 ). In PHS, supra note 12 and Carter v Canada (Attorney General), 2015 SCC 5, [2015] 1 SCR 331 [Carter], the Supreme Court considered and rejected on their merits attempts to invoke IJI on behalf of provincial authority. For present purposes, it is not necessary to resolve this issue. But the paucity of precedent using IJI successfully to protect provincial authority, coupled with the Supreme Court's repeated recent insistence that IJI should be confined to situations already covered by precedent (see e.g. Canadian Western Bank, supra note 11 at para 77; Ryan Estate, supra note 12 at para 50; Rogers, supra note 13 at para 61), suggests, on the Supreme Court's own reasoning, that IJI will rarely, if ever, be available to protect provincial authority.

[1988] 1 SCR 749 at 841 [Bell Canada (1988)]. See also Natural Parents $v$ Superintendent of Child Welfare, [1976] 2 SCR 751, Laskin CJC [Natural Parents] ("[i]t cannot be ... that because a provincial statute is general in its operation, in the sense that its terms are not expressly restricted to matters within provincial competence, it may embrace matters within exclusive federal competence" at 760). Robin Elliot, "Interjurisdictional Immunity after Canadian Western Bank and Lafarge Canada Inc: The Supreme Court Muddies the Doctrinal Waters - Again" (2008) 43 SCLR (2d) 433 at 493. COPA, supra note 13 at para 48.

Ibid at para 53. See also ibid at para 60.

Ibid at paras 66-74. 
How one feels about IJI depends on the importance one ascribes to ensuring that exclusive federal authority - the "powers relating to matters of national importance" $" 60$ — is available only to the federal order, and that Parliament is free to exercise (or not to exercise) that legislative authority as it chooses.

As mentioned above, the Supreme Court has, in recent years, shown considerable impatience with IJI. IJI, it has said, "is of limited application and should in general be reserved for situations already covered by precedent." ${ }^{61}$ In "the absence of prior case law favouring [IJI's] application to the subject matter at hand," it is perfectly fitting, in the Supreme Court's view, to omit the IJI inquiry. ${ }^{62}$ Reasons for this generic impatience reappear in Tsilhqot'in. ${ }^{63}$ We shall return to them. ${ }^{64}$

\section{THE DAY BEFORE TSILHQOT'IN}

So far, we have seen that: (1) a rational federal system such as Canada's allocates different legislative powers to its different orders of government, assigning to each one exclusive authority over those matters it is best placed to address; (2) the integrity of such a system depends, therefore, in significant part on protecting each order of government's reserve of exclusive authority; (3) the framers entrusted legislative authority over "Indians, and Lands reserved for the Indians" exclusively to the federal order, most probably because they recognized that Indigenous peoples and their lands needed protection from the competing interests of local settlers and governments; and (4) IJI ensures that even valid provincial legislation cannot achieve effects or results reserved exclusively to federal authority.

One could have asserted all of this with reasonable confidence on 25 June 2014, the day before the Tsilhqot'in decision emerged. The interesting question on that date, especially given the Supreme Court's explicit instruction to confine IJI to situations already covered by precedent ${ }^{65}$ was whether Indigenous peoples' existing treaty and Aboriginal rights lay within IJI's protection at the core of exclusive federal authority under section 91(24).

In respect of the rights in Indigenous treaties, the answer almost certainly would have been "yes." In R. v. White and Bob, ${ }^{66}$ the Supreme Court, in a one-paragraph endorsement, agreed with a majority of the British Columbia Court of Appeal that provisions in the British Columbia Game $A c t^{67}$ were inapplicable to Indians exercising hunting rights set out in the 1854 Douglas Treaties. Both Court of Appeal judges whose opinions formed the majority had held that only Parliament could abrogate or abridge rights contained in treaties with

Moloney, supra note 20 at para 14.

Canadian Western Bank, supra note 11 at para 77, cited with approval in Ryan Estate, supra note 12 at para 50; Rogers, supra note 13 at para 61.

Canadian Western Bank, ibid at para 78. See also PHS, supra note 12 ("before applying the doctrine of [IJI] in a new area, courts should ask whether the constitutional issue can be resolved on some other basis" at para 65$)$.

Supra note 1.

See notes $166-67,169-82$, below, and accompanying text.

Canadian Western Bank, supra note 11 at para 77; Rogers, supra note 13 at para 61.

(1965), 52 DLR (2d) 481 (SCC) [White and Bob], aff'g (1964), 50 DLR (2d) 613 (BCCA) [White and Bob CA].

RSBC 1960, c 160. 
Indigenous peoples. ${ }^{68}$ Twenty years later, in Simon v. $R .{ }^{69}$ the Court, citing White and Bob CA, observed with approval that "[i]t has been held to be within the exclusive power of Parliament under s. 91(24) of the Constitution Act, 1867, to derogate from rights recognized in a treaty agreement made with the Indians." ${ }^{, 70}$ Another twenty years later, in R. v. Morris, ${ }^{71}$ the majority and dissenting judgments reached the same conclusion, agreeing that Indigenous peoples' treaty rights "lie squarely within federal jurisdiction over 'Indians, and Lands reserved for the Indians." "72 The only arguable exception was an aside included in $R$. $v$. Marshall, ${ }^{73}$ a decision that had nothing to do with provincial regulation or authority. On the day before the Tsilhqot'in decision, the better view would clearly have been that treaty rights came under IJI protection within exclusive federal legislative authority. ${ }^{74}$

The status of Aboriginal rights on that date was more complicated. In Delgamuukw, the Supreme Court confirmed that "s. 91(24) [of the Constitution Act, 1867] protects a 'core' of Indianness from provincial intrusion, through the doctrine of [IJI]."75 "That core," it said, "encompasses aboriginal rights, including the rights that are recognized and affirmed by s. 35(1) [of the Constitution Act, 1982]." "76 This conclusion, it added, followed because it had characterized such rights "as protecting the occupation of land and the activities which are integral to the distinctive aboriginal culture of the group claiming the right." in Paul v. British Columbia (Forest Appeals Commission), the Supreme Court reaffirmed that "[t]he 'core' of Indianness ... encompasses the whole range of aboriginal rights that are protected by s. 35(1)"78 and that provincial laws that "trench upon the core of Indianness" will be inapplicable by virtue of IJI. ${ }^{79}$ But those same two decisions also said that provinces

White and Bob CA, supra note 66 at 618, 647-48, 663-64, Davey and Norris JJA. Both judges also held that the opening words of section 87 of the Indian Act, RSC 1952, c 149 (now RSC 1985, c I-5, s 88) precluded provincial laws of general application from applying to the exercise of Indians' treaty rights). We now know this to be true only if treaty rights come within the core of exclusive federal authority, because section 88 applies only to valid provincial laws that, because of IJI, cannot apply as provincial laws to Indians (Dick $v$ R, [1985] 2 SCR 309 at 326-28 [Dick]; Derrickson v Derrickson, [1986] 1 SCR 285 at 297 [Derrickson]; R v Francis, [1988] 1 SCR 1025 at 1031; Delgamuukw, supra note 15 at para 182).

[1985] 2 SCR 387 [Simon].

Ibid at 411.

2006 SCC 59, [2006] 2 SCR 915 [Morris].

Ibid at para 43, Deschamps and Abella JJ, for the majority. See also ibid at paras 83 ("Aboriginal and treaty rights fall squarely within Parliament's jurisdiction under s. 91(24)"), 91 ("Indian treaty rights and aboriginal rights have been held to fall within the protected core of federal jurisdiction .... It follows that provincial laws of general application do not apply ex proprio vigore to the hunting activities of Indians that are protected by a treaty" [citation omitted]), McLachlin CJC and Fish J, dissenting on other grounds.

73 [1999] 3 SCR 533 at para 24 [Marshall 2]:

The Court was thus most explicit [in $R$ v Marshall, [1999] 3 SCR 456 [Marshall]] in confirming

the regulatory authority of the federal and provincial governments within their respective legislative fields to regulate the exercise of the treaty right subject to the constitutional requirement that restraints on the exercise of the treaty right have to be justified on the basis of conservation or other compelling and substantial public objectives.

Marshall, ibid, had said nothing about provincial regulation or authority.

See also McIvor \& Gunn, supra note 45 at 153.

Delgamuukw, supra note 15 at para 177. See also ibid at para 181 .

Ibid at para 178 .

Ibid at para 181 .

2003 SCC 55, [2003] 2 SCR 585 at para 33 [Paul].

Ibid at para 16 . 
may infringe Aboriginal rights when they can justify doing so.$^{80}$ These propositions cannot both be right. ${ }^{81}$

This brings us, at last, to Tsilhqot'in. "The ambiguous state of the jurisprudence" on IJI and Aboriginal rights, the Supreme Court observed, "has created unpredictability." undertook to dispel the confusion and restore doctrinal order.

\section{TSILHQOT'IN, SECTION 35 RIGHTS, AND INTERJURISDICTIONAL IMMUNITY}

The Supreme Court's solution in Tsilhqot'in was to deny IJI protection to Aboriginal rights, rendering those rights susceptible to justified provincial infringement. In Grassy Narrows, it needed just two sentences to adopt and apply this rationale to treaty rights, ${ }^{83}$ erasing, without acknowledgment, fifty years of contrary treaty rights jurisprudence ${ }^{84}$ This course has the virtue of resoluteness and, as mentioned earlier, ${ }^{85}$ considerable initial pragmatic appeal. But the reasoning offered in its support is, with due respect, uncommonly careless and tendentious, especially for a unanimous Supreme Court of Canada judgment. The result has been to exacerbate the doctrinal instability the Supreme Court had set out to cure.

One finds the relevant reasons at paragraphs $128-52$ of Tsilhqot'in. ${ }^{86}$ They deserve to be read in full, but the following is a brief summary:

(1) "[F] or constitutional purposes, forestry on Aboriginal title land possesses a double aspect, with both levels of government enjoying concurrent jurisdiction." ${ }^{87}$ IJI

Delgamuukw, supra note 15 ("[t]he aboriginal rights recognized and affirmed by s. 35(1), including aboriginal title, are not absolute. Those rights may be infringed, both by the federal ... and provincial ... governments. However, s. 35(1) requires that those infringements satisfy the test of justification" at para 160 [citations omitted]); Paul, ibid at paras 10 ("[o]nce an aboriginal right is proven, [a provincial statutory provision] would be of no effect to the extent that it was inconsistent with that right, unless that inconsistency could be justified"), 24 ("[u]nless otherwise specified ... every right in the Constitution Act, 1982 applies to every province as well as to the federal government.... It is also established that one part of the Constitution cannot abrogate another.... By virtue of s. 35, then, laws of the province of British Columbia that conflict with protected aboriginal rights do not apply so as to limit those rights, unless the limitation is justifiable"), 25 ("Sparrow [supra note 14] stands for the proposition that government regulation, including provincial regulation, may, by legislation, infringe an aboriginal right if that infringement is justified").

81 Compare McIvor \& Gunn, supra note 45 at 152-53.

82 Tsilhqot'in, supra note 1 at para 138.

83 Supra note 3 (" $[t]$ he doctrine of [IJI] does not preclude the Province from justifiably infringing treaty rights (Tsilhqot'in Nation v. British Columbia, 2014 SCC 44, [2014] 2 S.C.R. 256). While it is unnecessary to consider this issue, this Court's decision in Tsilhqot'in Nation is a full answer" at para 53). For the record, I agree that IJI jurisprudence must not differentiate between Aboriginal rights and treaty rights; IJI must protect both, or neither. Any differentiation between the two kinds of rights would be invidious, generating perverse incentives, for one side or the other, in any future treaty negotiations. For discussion of this, see Kerry Wilkins, "Of Provinces and Section 35 Rights" (1999) 22:1 Dal LJ 185 at 201-203.

$84 \quad$ See supra notes 66-73 and accompanying text.

See supra notes $14-15$ and accompanying text.

Supra note 1 .

Ibid at para 129. This is so, the Supreme Court says, because "forestry on Aboriginal title land falls under both the provincial power over forestry in the province and the federal power over "Indians" (ibid). 
protects from provincial legislation only the protected core of federal legislative authority. ${ }^{88}$

(2) The Supreme Court's previous jurisprudence on Aboriginal rights and provincial authority is "somewhat mixed" and, apart from Morris, ${ }^{89}$ entirely obiter dicta..$^{90}$ Further, Morris, on this issue, "should no longer be followed."

(3) Aboriginal rights, like Charter rights, are rights against both orders of government. The division of powers has nothing to do with them. Situating such rights within exclusive federal authority would mean applying different standards to provincial than to federal infringements of them. That would be absurd. ${ }^{92}$

(4) Invoking IJI in respect of Aboriginal rights "would create serious practical difficulties," 93 requiring "two different tests for assessing the constitutionality of provincial legislation affecting Aboriginal rights," "94 risking "legislative vacuums" $" 95$ and discouraging cooperative federalism. ${ }^{96}$

None of these propositions survives careful scrutiny.

\section{A. Double ASPECt? ConCURRent JuRisdiction?}

The current controversy concerns a great deal more than just "forestry on Aboriginal title land," but the Supreme Court's unsupported assertion that both orders of government share concurrent jurisdiction over that matter ${ }^{97}$ presupposes the outcome of its inquiry into the relationship between IJI and section 35 rights. Where both orders of government have concurrent jurisdiction over the same subject matter, it follows necessarily that the matter cannot lie within exclusive federal authority or claim protection from IJI. Some argument or authority in support of this assumption would have been welcome.

A double aspect is something different; it speaks to the validity, not the applicability, of the relevant legislation. Generic provincial forestry legislation could well be valid despite not expressly excluding Aboriginal title lands (as could generic federal legislation on Aboriginal title that did not expressly exclude forestry), but that tells us nothing useful about whether such a provincial law would be applicable on or to such lands. ${ }^{98}$ Considerable previous authority suggests that it would not. Recall first the Privy Council's determination in St. Catherine's Milling that all lands reserved for Indians are to "be under the legislative control

Ibid at para 131 .

Supra note 71.

Tsilhqot'in, supra note 1 at para 135.

Ibid at para 150. "To the extent that Morris stands for the proposition that provincial governments are categorically barred from regulating the exercise of Aboriginal rights, it should no longer be followed" (ibid).

Ibid at paras $141-43$.

Ibid at para 145 .

Ibid at para 146 .

Ibid at para 147.

Ibid at para 149 .

Ibid at para 129.

COPA, supra note 13 (double aspects do not preclude IJI). See ibid at paras 54-59. 
of one central authority" in the interest of "uniformity of administration." 99 We have been given to understand, as well, that Aboriginal title lands qualify as "Lands reserved for the Indians," 100 that the Aboriginal interest in Aboriginal title lands is functionally equivalent to that in reserve lands, ${ }^{101}$ and that "presumably the matters contained within exclusive federal authority over Indian reserve lands include regulation of the manner of landholding, disposition of interests in reserve lands and how reserve lands may be used (for example, zoning regulations)." ${ }^{\prime 102}$ Forestry, surely, is a use of land - one can hardly engage in forestry without using land - so regulating forestry on Aboriginal title lands is regulating use of such lands. ${ }^{103}$ And allocation of forest tenures in respect of particular lands is a "disposition of interests" in them. ${ }^{104}$ From this, one would have thought it followed that generic provincial forestry legislation would be constitutionally inapplicable to Aboriginal title land, and provincial legislation aimed at forestry on such land invalid.

But the Supreme Court in Tsilhqot'in did not acknowledge any of this authority, inviting us to wonder whether it meant to overrule it, or whether it was simply overlooked. We shall have reason for similar wonder again later on.

\section{B. SECTION 35 AND INTERJURISDICTIONAL IMMUNITY: The Previous Jurisprudence}

It was reasonable, in my judgment, for the Supreme Court to describe its previous jurisprudence on Aboriginal rights and IJI ${ }^{105}$ as "somewhat mixed." 106 It was reasonable, too, for it to describe as obiter dicta ${ }^{107}$ all its suggestions prior to those in Tsilhqot'in that section 35 equips the provinces, as well as the federal order, to justify, if they can, their infringements of Aboriginal rights. ${ }^{108}$ In neither Delgamuukw ${ }^{109}$ nor Paul ${ }^{110}$ did the Supreme Court conclude that the claimant community had an Aboriginal right, let alone that any provincial legislation or conduct infringed one. In neither, therefore, did it need to comment on provincial capacity to justify infringements of such rights. Likewise, although Paul was, in a sense, about IJI, ${ }^{111}$ it is fair to describe as obiter the Supreme Court's observations about the "core of Indianness." 112 It could have decided Paul without ever mentioning that issue. The same, of course, is true of both Tsilhqot'in and Grassy Narrows. ${ }^{113}$

Supra note 29 at 59.

Constitution Act, 1867, supra note 16, s 91(24). See also ibid; Delgamuukw, supra note 15 at paras 174-75.

Quebec (AG) v Canada (AG), [1921] 1 AC 401 (PC) at 410-11; Guerin v R, [1984] 2 SCR 335 at 379; Delgamuukw, ibid at para 120; Osoyoos Indian Band v Oliver (Town), 2001 SCC 85, [2001] 3 SCR 746 at para 41 .

Derrickson, supra note 68 at 295, quoting with approval KM Lysyk, "Constitutional Developments Relating to Indians and Indian Lands: An Overview" (1978) LSUC Special Lectures 201 at 227, n 49. I deal with this issue in much greater detail in Kerry Wilkins, "Negative Capability: Of Provinces and Lands Reserved for the Indians" (2002) 1 Indigenous LJ 57 at 68-78, 89-97.

See supra note 102 and accompanying text.

See supra notes 75-80 and accompanying text.

Tsilhqot'in, supra note 1 at para 135.

Ibid.

See supra note 80 .

Supra note 15.

Supra note 78 .

Ibid. The case concerned whether provinces had constitutional authority to equip their tribunals to consider such questions of Aboriginal right as arose from matters otherwise properly before them.

Ibid at para 12 .

See supra notes 7-10 above and accompanying text. 
By the usual standards, however, the Supreme Court's discussion in Delgamuukw of exclusive federal authority was essential to the conclusions it reached on one of the issues before it. There, British Columbia sought and received leave to cross-appeal specifically about whether it had the power, before 1982, "to extinguish the rights of aboriginal peoples, including aboriginal title, in that province," directly, by means of laws of general application, or via section 88 of the Indian Act. ${ }^{114}$ The Supreme Court concluded unanimously that British Columbia had no such authority. ${ }^{115}$ Provinces could not extinguish Aboriginal title because Aboriginal title lands are "Lands reserved for the Indians" for purposes of section 91(24). Section 91(24) "carries with it the jurisdiction to legislate in relation to aboriginal title. It follows, by implication, that it also confers the jurisdiction to extinguish that title."116 Provinces could not extinguish other Aboriginal rights because such rights lay at the core of exclusive federal legislative authority over "Indians." 117 And otherwise valid provincial laws of general application could not, for two reasons, operate to extinguish Aboriginal rights or title: (1) because no valid provincial law of general application could display a "sufficiently clear and plain intention to extinguish"; ${ }^{118}$ and (2) because "s. 91(24) protects a core of federal jurisdiction even from provincial laws of general application, through the operation of the doctrine of [IJI]."119

In brief, Delgamuukw was a precedent. The Supreme Court could not have decided the cross-appeal there without determining whether provinces had capacity to extinguish Aboriginal title, and it could not have concluded that they lacked such capacity (before 1982) without concluding that Aboriginal rights and title lay within exclusive federal legislative authority.

This matters here because the Supreme Court in recent years has considered the presence or absence of precedent all but dispositive in deciding whether to invoke, or sometimes even to consider invoking, IJI. ${ }^{120}$ "Predictability, important to the proper functioning of the division of powers, requires," the Supreme Court said in PHS, "recognition of previously established exclusive cores of power." precedent.

Equally so was Morris, ${ }^{122}$ the one potential precedent the Supreme Court did acknowledge in Tsilhqot'in. ${ }^{123}$ Morris, the Supreme Court said, is no longer good law, because it "was

Delgamuukw, supra note 15 at para 4 . See also ibid at para 72.

Ibid at paras 172-83, Lam
McLachlin J, concurring. 116 Ibid at para 174. The fact that the province held the underlying title to the Aboriginal title lands did not
affect the exclusivity of federal authority to legislate in relation to such lands or to extinguish the Aboriginal interest in them.

Ibid at para 178. "Laws which purport to extinguish those rights," the Court concluded, "therefore touch the core of Indianness which lies at the heart of s. 91(24), and are beyond the legislative competence of the provinces to enact" (ibid).

$118 \quad$ Ibid at para 180.

$119 \quad$ Ibid at para 181. See also ibid at para 177.

See COPA, supra note 13 at paras 36-37; Rogers, supra note 13 at paras 61-65; Ryan Estate, supra note 12 at para 49.

PHS, supra note 12 at para 65. The Supreme Court acknowledged that "new areas of exclusive jurisdiction could in theory be identified in the future," but added quickly that "courts are reluctant to identify new areas where [IJI] applies" (ibid at para 67).

Supra note 71.

Tsilhqot'in, supra note 1 at para 137. 
decided prior to this Court's articulation of the modern approach to [IJI] in Canadian Western Bank and [COPA]." ${ }^{124}$ In this, of course, Morris is hardly unique. The same is true of any precedent about IJI (including Delgamuukw) decided before Canadian Western Bank. If this were sufficient disqualification, the Supreme Court could not insist in good faith that precedent was its touchstone for future use in invoking or considering IJI; nothing of interest could qualify. But there have been cases both before ${ }^{125}$ and after ${ }^{126}$ Tsilhqot'in in which the Supreme Court has relied on precedents decades older than Morris to anchor and deploy IJI on behalf of exclusive federal legislative authority. This invites explanation. Selective reliance on precedent is not, without more, reliance on precedent.

And Morris is, by any standard, a curious candidate for disqualification. It is true that the Supreme Court in Morris did not have the benefit of its published reasons in Canadian Western Bank, because it decided Morris (released 21 December 2006) shortly before it decided Canadian Western Bank (released 31 May 2007). It is also true, however, that the Morris appeal (heard 14 October 2005) was under reserve when the Supreme Court heard argument in Canadian Western Bank (11 April 2006). Both appeals were under reserve together for just over eight months. Is it conceivable that the Supreme Court, while preparing Canadian Western Bank, had no idea what it was going to say (or later, what it had said) in Morris, or that it had no idea, when it released Morris, what it proposed to say in Canadian Western Bank $?^{127}$ It would be extraordinary, and troubling, for the Supreme Court to issue incompatible rulings five months apart on the same significant constitutional issue. Besides, as I have argued elsewhere, ${ }^{128}$ Canadian Western Bank specifically accommodates ongoing resort to IJI in respect of "those heads of legislative authority" — including section 91(24) — "that confer on Parliament power over enumerated federal things, people, works or undertakings," 130 and the reasoning in Morris arguably comports with the "more restricted approach"131 to IJI preferred in Canadian Western Bank.

Finally, it is of interest that Tsilhqot'in overruled Morris, a treaty rights case, without acknowledging either Simon ${ }^{132}$ or White and Bob, ${ }^{133}$ precedents on which the Morris panel relied for its conclusions about section 91(24) and treaty rights. Instead it juxtaposed, as worthy of roughly equal weight, a version of the comment, unanchored in authority, it had made in passing on the subject in Marshall $2,{ }^{134}$ a case, again, that involved only federal authority to regulate treaty rights. ${ }^{135}$ The Supreme Court's decision to prepare any written

Ibid at para 150 .

COPA, supra note 13, relying on Johannesson v Municipality of West St Paul (1951), [1952] 1 SCR 292. Rogers, supra note 13, relying on Toronto Corporation v Bell Telephone Co of Canada (1904), [1905] AC 52 (PC).

Six of the seven judges who sat on the Morris appeal - Chief Justice McLachlin and Justices Bastarache, Binnie, Fish, Abella, and Charron - also heard the appeal in Canadian Western Bank. Justice Deschamps was the seventh judge on the Morris panel, Justice LeBel the seventh on Canadian Western Bank.

Kerry Wilkins, "R. v. Morris: A Shot in the Dark and Its Repercussions" (2008) 7:1 Indigenous LJ 1 at 21-23.

See Canadian Western Bank, supra note 11 at paras 60-61.

Ibid at para 67.

Ibid at paras $48-53$.

Supra note 69.

Supra note 66.

See supra note 73 and accompanying text.

See Tsilhqot'in, supra note 1 at paras 136-37. 
reasons in Marshall 2 was unusual and, strictly speaking, unnecessary. ${ }^{136}$ Supreme Court pronouncements do not get much more obiter than that.

\section{Rights Against Government: The Charter AnAlogy}

Aboriginal rights, like Charter rights, are, the Supreme Court says in Tsilhqot'in, rights "held against government" 137 — both orders of government. They operate as limits "on both federal and provincial jurisdiction." 138 "These limits have nothing to do with whether something lies at the core of the federal government's powers." 139 Applying IJI in the Charter context would preclude the provinces from justifying their infringements of Charter rights; that, the Supreme Court says, would be just absurd. "This same absurdity would result if [IJI] were applied to Aboriginal rights."

Aboriginal rights differ from Charter rights in one potentially key respect. Charter rights, as such, are not enforceable against the whole world; the Charter applies only to, and is enforceable only against, those governmental entities contemplated in section 32 of the Charter. ${ }^{141}$ Aboriginal rights, on the other hand, though indeed enforceable against governments (federal and provincial), are not necessarily enforceable exclusively against governments. ${ }^{142}$ To qualify for constitutional protection under section 35 of the Constitution Act, 1982, Aboriginal rights must have been in existence - whether we knew it or not before and apart from section $35,{ }^{143}$ under the common law. ${ }^{144}$ Common law rights are presumptively enforceable against any entity, public or private, that infringes them. Courts have considered on their merits claims of Aboriginal right in civil proceedings among only private parties. ${ }^{145}$ Division of powers principles, and even IJI, might well prove useful in testing the authority of legislation purporting to govern Aboriginal rights or claims in private civil proceedings. We already know, for example, that validly enacted provincial limitation periods cannot preclude civil actions based on Aboriginal interests in reserve land. ${ }^{146}$

Marshall 2, supra note 73 provides the Supreme Court's reasons for dismissing an intervener's request that it re-hear and reconsider its decision earlier that year in Marshall, supra note 73. This was a singular (though perhaps, in the circumstances, understandable) exception to the Supreme Court's much more usual practice of deciding rehearing motions without giving reasons.

Tsilhqot'in, supra note 1 at para 142 [emphasis in original].

Ibid at para 141

Ibid at para 142 .

Ibid at para 143 .

See e.g. RWDSU v Dolphin Delivery Ltd, [1986] 2 SCR 573; McKinney v University of Guelph, [1990] 3 SCR 229; $R v$ Harrer, [1995] 3 SCR 562; $R$ v Terry, [1996] 2 SCR 207; Eldridge v British Columbia (Attorney General), [1997] 3 SCR 624; Schreiber v Canada (Attorney General), [1998] 1 SCR 841. In this one respect, treaty rights may well resemble Charter rights more than they do Aboriginal rights. Non-governmental parties have made no treaty promises to Indigenous groups.

See e.g. Sparrow, supra note 14 at 1091; Delgamuukw, supra note 15 at para 133.

See e.g. $R v$ Van der Peet, [1996] 2 SCR 507 at paras 28-29 [Van der Peet].

See e.g. Thomas $v$ Norris, [1992] 2 CNLR 139 (BCSC) (Aboriginal right asserted unsuccessfully as a defence to a tort claim); Manychief v Poffenroth (1994), [1995] 3 WWR 210 (Alta QB) [Manychief] (Aboriginal right was available in principle in support of a tort claim, but the plaintiff could not demonstrate the exercise of a relevant Aboriginal right). At least two civil proceedings now underway in the lower courts are actions against private parties for infringements of Aboriginal rights: see Saik' $u z$ First Nation and Stellat'en First Nation v Rio Tinto Alcan Inc, 2015 BCCA 154, [2015] 12 WWR 67, rev'g in part 2013 BCSC 2303, [2014] 2 CNLR 330; Compagnie minière IOC inc c Uashaunnuat (Innus de Uashat et de Mani-Utenam), 2015 QCCA 2, 2015 QCCA 2 (CanLII), aff'g 2014 QCCS 4403, 2014 QCCS 4403 (CanLII).

146 Canadian Pacific Ltd v Paul, [1988] 2 SCR 654 at 673; see also Stoney Creek Indian Band v British Columbia, [1999] 8 WWR 709 at paras 48-69, rev'd on other grounds 1999 BCCA 527, 179 DLR (4th) 57; Chippewas of Sarnia Band v Canada (Attorney General) (2000), 51 OR (3d) 641 (CA) at paras 220-42. In Canada (Attorney General) v Lameman, 2008 SCC 14, [2008] 1 SCR 372, the Supreme 
But never mind that. Assume for now the soundness of the Supreme Court's analogy between Charter and Aboriginal rights. Here, in full, is the relevant text from Tsilhqot'in:

\begin{abstract}
Parliament enjoys exclusive jurisdiction over criminal law. However, its criminal law power is circumscribed by s. 11 of the Charter which guarantees the right to a fair criminal process. Just as Aboriginal rights are fundamental to Aboriginal law, the right to a fair criminal process is fundamental to criminal law. But we do not say that the right to a fair criminal process under s. 11 falls at the core of Parliament's criminal law jurisdiction. Rather, it is a limit on Parliament's criminal law jurisdiction. If s. 11 rights were held to be at the core of Parliament's criminal law jurisdiction such that [IJI] applied, the result would be absurd: provincial breaches of s. 11 rights would be judged on a different standard than federal breaches, with only the latter capable of being saved under s. 1 of the Charter. This same absurdity would result if [IJI] were applied to Aboriginal rights. ${ }^{147}$
\end{abstract}

The choice of example here is revealing. Had the Supreme Court considered instead the Charter right to freedom of religion, ${ }^{148}$ or "freedom of thought, belief, opinion and expression, including freedom of the press," 149 both of which now also limit Parliament's legislative authority, ${ }^{150}$ it would have had to reckon with pre-Charter decisions (its own, and those of the Privy Council) invalidating provincial laws that purported to require religious observance, ${ }^{151}$ or to regulate the permissible content of public discussion ${ }^{152}$ or political speech or activity. ${ }^{153}$ Those laws were invalid, these Courts concluded, because the power to enact them lay exclusively with the federal order of government. They would still be invalid today.

Consider now a different example. Imagine that identical provisions contravening section 15 of the Charter appear in both federal and provincial legislation regulating insurance. ${ }^{154}$ Courts would rightly entertain argument seeking to justify the discriminatory provincial measure, but Canada deserves no opportunity to justify its infringement - regulation of insurance contracts lies exclusively within provincial legislative authority. ${ }^{155}$ The federal law would be invalid irrespective of the Charter breach. Application of different, well-accepted constitutional standards does not always disadvantage the provincial order.

Court used Alberta's limitations legislation to bar a complex historical claim that included allegations of treaty breach, but had not been asked to consider whether the Act was constitutionally applicable to such claims. Section 32 of the federal Crown Liability and Proceedings Act, RSC 1985, c C-50, as amended, would in any event have incorporated and applied the provincial limitation period as federal law to actions against the federal Crown. Tsilhqot'in, supra note 1 at para 143 [emphasis in original].

Charter, supra note 23, s 2(a).

Ibid, s 2(b).

See e.g. $R$ v Big M Drug Mart Ltd, [1985] 1 SCR 295 (freedom of religion); $R v$ Zundel, [1992] 2 SCR 731 (freedom of expression).

See e.g. Ontario (AG) v Hamilton Street Railway, [1903] AC 524 (PC); In re Legislation Respecting Abstention from Labour on Sunday (1905), 35 SCR 581 (provincial Sunday closing law deemed invalid). See e.g. Reference re Alberta Statutes, [1938] SCR 100 at 132-35, Duff CJC; at 146, Cannon J. See also Alberta (AG) v Canada (AG), [1938] AC 117 (PC), where the Privy Council dismissed the appeal from this decision as moot, but in doing so did "not intend to intimate any doubt as to the correctness of the decision of the Supreme Court as regards" the relevant legislation (ibid at 128). Compare Saumur v City of Quebec, [1953] 2 SCR 299 at 329-33, Rand J; at 343-56, Kellock J; at 359, Estey J; at 372-77, Locke J.

See e.g. Switzman v Elbling, [1957] SCR 285 (provincial law prohibiting promulgation in writing of Bolshevism or communism deemed invalid).

See e.g. Miron v Trudel, [1995] 2 SCR 418 (discriminatory distinction in provincial insurance legislation between legally married and common law couples).

See Citizens Insurance Co of Canada v Parsons, [1881] UKPC 49, [1881] 7 AC 96; Canada (AG) v Alberta (AG), [1916] 1 AC 588 (PC); Re Reciprocal Insurance Legislation, [1924] AC 328 (PC). 
The point of these examples is that the enactment of the Charter had no effect on preexisting legislative authority. The Charter itself tells us so. ${ }^{156}$ The Charter provides the rights it contains with a layer of protection additional to that which they derive from the preexisting division of constitutional authority. The justification regime prescribed in section 1 of the Charter is indeed available to both provincial and federal orders, but only when the constitutional problem they face is exclusively one of Charter compliance. When a constitutional defect having to do with speech, religion, or insurance regulation, for instance, results from transgression of the division of powers, the Charter has nothing to do with it. This is why courts typically address any division of powers challenges to impugned legislative provisions before considering whether those provisions infringe the Charter; ${ }^{157}$ answering the division of powers question in the negative concludes the constitutional inquiry. ${ }^{158}$

This is equally true of section 11 of the Charter. The enactment of section 11 did not give the provinces fresh authority over criminal law; Parliament, as Tsilhqot'in says, still "enjoys exclusive jurisdiction over criminal law." "I59 It is true that section 11 rights do not lie at the core of federal authority over criminal law, and that provinces, therefore, may seek to justify their section 11 infringements. ${ }^{160}$ But that is so because the provinces already had some independent legislative authority over matters to which section 11 pertains. Section 11 rights do not deal only with fair criminal process - they extend to "[a]ny person charged with an offence." ${ }^{\prime 161}$ Not all offences are criminal offences; provinces may create non-criminal offences and provide for their enforcement. ${ }^{162}$ And section 11 does nothing to re-frame the relationship or to reset the boundary between Parliament's exclusive authority over criminal law and procedure ${ }^{163}$ and the provinces' authority over " $[\mathrm{t}]$ he Administration of Justice in the Province." 164 If otherwise unimpeachable provincial legislation infringes section 11, the province may seek to justify the infringement. But if provincial legislation that is invalid or inapplicable on other grounds also happens to infringe section 11, the section 11 infringement does not create a justification opportunity that the province otherwise would not have.

The Supreme Court's analogy to the Charter and the criminal law does not, therefore, help support its conclusion that provinces may, despite IJI, seek to justify Aboriginal rights infringements. The division of powers operates no differently than it ever did in respect of penal matters: before and apart from any inquiry into the Charter's impact. The Charter has neither expanded provincial nor diminished exclusively federal legislative authority. If this

Charter, supra note 23, s 31 ("[n]othing in this Charter extends the legislative powers of any body or authority").

See $R v$ Edwards Books and Art Ltd, [1986] 2 SCR 713; Irwin Toy Ltd v Quebec (Attorney General), [1989] 1 SCR 927; PHS, supra note 12; Carter, supra note 54; Goodwin v British Columbia (Superintendent of Motor Vehicles), 2015 SCC 46, [2015] 3 SCR 250.

See $R v$ Morgentaler, [1993] 3 SCR 463 at 472-74, 478 (unnecessary to consider Charter issues because the legislation was beyond provincial legislative authority). Cf Simon, supra note 69 at 414-15 (unnecessary to consider section 35 of the Constitution Act, 1982 because the provincial law was inapplicable on division of powers grounds).

Supra note 1 at para 143 .

Examples of attempts to invoke section 11 in respect of provincial offence proceedings include $R v$ EllisDon Ltd, [1992] 1 SCR 840; $R v$ CIP Inc, [1992] 1 SCR 843; $R v$ Richard, [1996] 3 SCR 525.

Charter, supra note 23, s 11 .

Constitution Act, 1867, supra note 16, s 92(15).

Ibid, s 91(27).

Ibid, s 92(14). 
is the paradigm we are to use in testing provincial capacity to infringe Aboriginal rights, it tells us to conduct that inquiry without reference to section 35, and that section 35 operates only after we confirm that the Constitution otherwise permits the relevant measure, whether federal or provincial. On this analysis, section 35 cannot count as a reason to answer a division of powers question in one way rather than another. ${ }^{165}$

\section{Of Dueling Tests and Practical Difficulties}

The Supreme Court's final major argument for denying IJI protection to section 35 rights accentuates IJI's reputed practical inconvenience. Leaving room for IJI would mean, it says, that there are "dueling tests directed at answering the same question: How far can provincial governments go in regulating the exercise of s. 35 Aboriginal rights?"166 And it could lead to "legislative vacuums" 167 and discourage productive federal-provincial cooperation. ${ }^{168}$

As suggested above, ${ }^{169}$ Canadian constitutional law is replete with dueling tests: necessarily so, because different criteria exist to detect different kinds of constitutional infirmities. Litigation often features several different possible grounds for doubting the constitutional soundness of something; when it does, courts have to consider applying more than one test in appraising the challenged measure. Any time someone challenges a provincial statute on both federalism and Charter grounds, for example, the Court must be prepared to consider whether the measure comes within provincial legislative authority, and whether it conflicts with valid and relevant federal law, as well as whether it infringes the Charter unjustifiably. This requires, surely, consideration of "dueling tests directed at answering the same question": in this hypothetical case, "[h]ow far ... provincial governments [can] go in regulating" 170 the exercise of the relevant Charter right. But no one finds such inquiries inappropriate or impractical merely because they require consideration of different legal tests to address the different constitutional issues. To suppose that dueling tests provide grounds for special concern only because one of those tests is the test for IJI, or the relevant right a section 35 right is, without more, just to beg the question.

The Supreme Court's concerns about legal vacuums and on behalf of cooperative federalism should be familiar; they have been frequent features of its generic discomfort with IJI since Canadian Western Bank. ${ }^{171}$ Detailed discussion of these concerns is beyond the scope of this article. ${ }^{172}$ They do, however, require brief comment here.

See Morris, supra note 71 (“[t]his justification analysis does not alter the division of powers" at para $55)$.

166 Tsilhqot'in, supra note 1 at para 146.

167 Ibid (" $\mathrm{t}$ t]he result would be patchwork regulation of forests - some areas of the province regulated under provincial legislation, and other areas under federal legislation or no legislation at all. This might make it difficult, if not impossible, to deal effectively with problems such as pests and fires, a situation desired by neither level of government" at para 147).

168 Ibid at paras 148-49.

169 See supra notes 148-58 and accompanying text.

170 Tsilhqot'in, supra note 1 at para 146.

171 Supra note 11 at paras 24 (cooperative federalism), 44 (legal vacuums). On cooperative federalism, see also $P H S$, supra note 12 at para 63. On legal vacuums, see also Lafarge, supra note 12 at para 4; PHS, ibid at paras 64,69 .

172 In "Straight Talk About Interjurisdictional Immunity," Sask L Rev [forthcoming], I deal at some length with these and other issues arising from the Supreme Court's recent IJI jurisprudence. 
Here are three quick thoughts about cooperative federalism. First, it is far from obvious that IJI has imposed any actual practical constraint on federal-provincial cooperation. Both orders of government have plenty of scope to delegate administrative powers to one another, enact regulations the other order has recommended or even drafted, ${ }^{173}$ and incorporate by reference into their own legislation laws validly enacted by the other order of government. Despite repeating often its concern for cooperative federalism, the Supreme Court has yet to provide an example where IJI has compromised or interfered with it. Second, there is no assurance that greater judicial tolerance for jurisdictional overlap will yield greater interjurisdictional cooperation. Where each may legislate as it will, cooperation between orders of government becomes less necessary and the potential for conflict somewhat greater. ${ }^{174}$ As Elliot suggested in 2008 , the better way to encourage federal-provincial cooperation might be to reduce, not expand, the degree of permissible overlap between their collections of legislative authority. ${ }^{175}$ Finally, the Supreme Court itself has acknowledged that cooperative federalism is not a dispositive constitutional value: that it, too, has limits. ${ }^{176}$ But if this is so, then we need a reason independent of cooperative federalism for saying that it deserves to outrank IJI in constitutional importance.

As for legal vacuums, IJI is not unique in Canadian constitutional law in its capacity to give rise to them. ${ }^{177}$ A substantial legal vacuum looms whenever a court declares a statute invalid on any constitutional grounds - division of powers, the Charter, section 35, section 96 , or language of enactment - in the absence of valid compensating legislation from the other order of government, yet no one considers this sufficient reason not to declare invalidity. What is it about IJI that gives this concern such special exigency? And we need to recall that discretion to close legal vacuums resides, where it belongs, with the order of government constitutionally empowered to do so. It has no constitutional obligation to legislate. When the Supreme Court suppresses IJI solely to avoid a legal vacuum, it substitutes its own judgment about the wisdom or desirability of particular legislation for that of the relevant legislative body. That is a substantial departure from traditional understandings of the judicial role. ${ }^{178}$

Finally, a measure of inconvenience is endemic to a polity with divided legislative authority, precisely because federalism - and indeed, the rule of law — sets limits on what either order of government may legitimately do and on how it may do it. In recent years, the Supreme Court has often shown itself quite tolerant of significant practical everyday inconvenience. It has precluded meaningful Senate reform without constitutional

173 See Peralta v Ontario, [1988] 2 SCR 1045, aff'g (1985), 49 OR (2d) 705 (CA).

174 See e.g. Quebec (Attorney General) v Canada (Attorney General), 2015 SCC 14, [2015] 1 SCR 693 [Quebec v Canada].

175 See Elliot, supra note 56 at 489.

176 See Reference re Securities Act, 2011 SCC 66, [2011] 3 SCR 837 at para 62 [Securities Reference], quoted with approval in Quebec v Canada, supra note 174 at para 19, and in Rogers, supra note 13 at para 39:

[N]otwithstanding the Court's promotion of cooperative and flexible federalism, the constitutional boundaries that underlie the division of powers must be respected. The "dominant tide" of flexible federalism, however strong its pull may be, cannot sweep designated powers out to sea, nor erode the constitutional balance inherent in the Canadian federal state.

See Re Upper Churchill Water Rights Reversion Act, [1984] 1 SCR 297 ("it is not for this Court to consider the desirability of legislation from a social or economic perspective where a constitutional issue is raised" at 334). 
amendment. ${ }^{179}$ It has invoked the division of powers to close the door on uniform national regulation of Canada's securities market. ${ }^{180}$ It has declared all unilingual Manitoba statutes invalid, ${ }^{181}$ and improvised to preserve public order until the constitutional defect could be rectified. ${ }^{182}$ And, not least, it has pointedly rejected elsewhere a submission "that aboriginal and treaty rights should be recognized only to the extent that such recognition would not occasion disruption or inconvenience to non-aboriginal people." ${ }^{183}$ The Supreme Court does not argue that shielding section 35 rights behind IJI would occasion greater practical inconvenience than any of these other deployments of constitutional discipline. Why, then, should potential practical inconvenience matter so much more to the outcome here than it has in these other situations?

\section{The AFTERMATH}

I hope by now to have shown in detail that the reasons the Supreme Court has given for refusing IJI protection to treaty and Aboriginal rights do not deserve to convince us. They ignore or dismiss a substantial body of previous jurisprudence that had explicated the scope and impact of section $91(24) ;{ }^{184}$ they overlook potentially important differences between Aboriginal rights and Charter rights; they load the dice by comparing section 35 rights to Charter rights that we already knew were subject to both federal and provincial legislative authority; they fail to acknowledge section 31 of the Charter or the Supreme Court's practice of considering division of powers issues before and apart from Charter issues that arise in the same proceeding; and they give what appears to be disproportionate weight to issues of practical inconvenience. In brief, they more closely resemble rationalization than rationale.

And even that, alas, is not the whole story. We have yet to canvass the disarray that Tsilhqot' in $^{185}$ and Grassy Narrows ${ }^{186}$ have introduced into section 91(24) jurisprudence. Fasten your seat belts.

See Reference re Senate Reform, 2014 SCC 32, [2014] 1 SCR 704.

See Securities Reference, supra note 176. Thanks to Constance Marlatt for reminding me of this. See Re Manitoba Language Rights, [1985] 1 SCR 721.

See especially ibid at 744-68.

Marshall 2, supra note 73 at para 45. "According to this submission," the Supreme Court continued, if a treaty right would be disruptive, its existence should be denied or the treaty right should be declared inoperative. This is not a legal principle. It is a political argument. What is more, it is a political argument that was expressly rejected by the political leadership when it decided to include s. 35 in the Constitution Act, 1982. The democratically elected framers of the Constitution Act, 1982 provided in s. 35 that "[ $\mathrm{t}$ ] he existing aboriginal and treaty rights of the aboriginal peoples of Canada are hereby recognized and affirmed" (emphasis added). It is the obligation of the courts to give effect to that national commitment. No useful purpose would be served by ... revisit[ing] such fundamental and incontrovertible principles.

Here, for interest's sake, are the guidelines the Supreme Court itself has provided for overruling its precedents. In Ontario (Attorney General) v Fraser, 2011 SCC 20, [2011] 2 SCR 3 [Fraser], Justice Rothstein, in concurring reasons said that "[t]here must be compelling reasons to justify overruling" (ibid at para 130), and that it "is not appropriate simply because of a change in the composition of the Court that precedent should be overturned, because of the views of newly appointed judges" (ibid). The majority agreed (ibid at para 56), emphasizing the special gravity of overturning multiple and recent precedents and the special care required "before reversing a precedent where the effect is to diminish Charter protection" (ibid at paras 57-58, quoting with approval $R v$ Henry, 2005 SCC 76, [2005] 3 SCR 609 at para 44). Finally, the majority held that it would be "procedurally inappropriate" for the Supreme Court to overrule any given precedent "[a]bsent notice to the profession and interested persons" (Fraser, ibid at para 59).

Supra note 1.

Supra note 3. 
The Supreme Court has told us that treaty and Aboriginal rights lie outside the core of exclusive federal legislative authority, and are therefore ineligible for IJI protection, today. That conclusion itself gives rise to significant doctrinal consequences. We shall get to them in due course. ${ }^{187}$ But we cannot gauge its full impact without ascertaining what else the Supreme Court is saying about IJI and (what we now know as) section 35 rights. We know that such rights existed, and had some enforceable legal effect, before section 35 took effect in 1982. Otherwise, there would be no "existing [A]boriginal and treaty rights" for section 35 to "recognize and affirm." 188 Is the Supreme Court now saying that these rights were never within the core of exclusive federal authority, and that this was always so, irrespective of section 35 ? Or is it saying that section 35 evicted such rights from the core of section 91(24) when it took effect in 1982 ?

The short answer is that we do not know. The Supreme Court does not consider this issue; one can find in its reasoning some support for either view. On the one hand, it aims explicitly at "the proposition that Aboriginal rights fall at the core of federal regulatory jurisdiction under s. 91(24) of the Constitution Act, 1867."189 One could have conducted that enquiry equally well before 1982. In doing so, one would have relied entirely on division of powers arguments. In principle, one could still do so today. A little later, the Supreme Court disapproves of resort to IJI in respect of Aboriginal title because "the problem in cases such as this is not competing provincial and federal powers, but rather tension between the right of the Aboriginal title holders to use their land as they choose and the province which seeks to regulate it, like all other land in the province." 190 This is a peculiar thing to say; previous IJI decisions have routinely featured tension between non-governmental parties (federally regulated works or undertakings, ${ }^{191}$ the estates of individuals killed in boating accidents, ${ }^{192}$ the owners of private aerodromes, ${ }^{193}$ adopted Indian children, ${ }^{194}$ for example) and the "province which seeks to regulate" their interests. In this respect, Tsilhqot'in and Aboriginal title are hardly unique. More to the present point, this proposition has nothing to do with section 35. Neither, finally, do the "serious practical difficulties" ascribes to IJI generically: the spectre of legislative vacuums and the putative disincentives to cooperative federalism. ${ }^{196}$ The Supreme Court has remarked on all this before, in decisions wholly unrelated to section $35 .{ }^{197}$ These concerns were no more or less sound, these practical difficulties no more or less pronounced, before section 35 took effect than they are today. All of this supports an inference that treaty and Aboriginal rights were never within the core of section 91(24).

Other passages, however, suggest the contrary conclusion. It is because of the protection section 35 affords to Aboriginal and treaty rights from both orders of government that, the

See notes $240-45$, below, and accompanying text.

See Sparrow, supra note 14 at 1091.

Tsilhqot'in, supra note 1 at para 134.

Ibid at para 144 .

See Commission du Salaire Minimum v Bell Telephone Co of Canada, [1966] SCR 767; Bell Canada (1988), supra note 55; Alltrans Express Ltd v British Columbia (Workers' Compensation Board), [1988] 1 SCR 897.

See Ordon Estate v Grail, [1998] 3 SCR 437; Ryan Estate, supra note 12.

See COPA, supra note 13.

See Natural Parents, supra note 55.

Tsilhqot'in, supra note 1 at para 145.

Ibid at paras $147-49$.

See supra notes 12, 171, above, and accompanying text. 
Supreme Court says, no role is "left for the application of the doctrine of [IJI] and the idea that Aboriginal rights are at the core of the federal power over "Indians." "198 It is only because of the Constitution Act, 1982 that the Supreme Court can attempt to analogize between the rights in the Charter (Part I of that Act) and the rights in section 35 (which comprise Part II). ${ }^{199}$ And it is only because of section 35 that "Aboriginal rights are a limit on both federal and provincial jurisdiction." ${ }^{200}$ If there were no section 35 , such rights, at a minimum, could not limit federal legislative authority. ${ }^{201}$ These observations suggest that section 35 is the reason the Supreme Court thinks treaty and Aboriginal rights do not belong at the core of section $91(24) .^{202}$

This matters because different issues arise, and different consequences ensue, depending on whether Aboriginal and treaty rights fell within the core of section 91(24) until 1982. None of these consequences is especially appealing; neither approach is especially consistent with previous law. It's best to consider them separately.

\section{A. THE "NEVER" HYPOTHESIS}

Suppose, then, that treaty and Aboriginal rights were never within what the Supreme Court has called "the core of Indianness": ${ }^{203}$ that zone of legislative authority, comprising matters that relate to "Indians ... qua Indians," 204 which section 91(24) reserves exclusively to the federal order of government. On its face, such a claim seems audacious. The rights we call "treaty rights" are rights that appear in agreements the Crown has made exclusively with Indigenous peoples. ${ }^{205}$ Such rights are available only to Indians, only because they are Indians. And Aboriginal rights, the Supreme Court has said, derive exclusively from "the practices, customs and traditions integral to the distinctive cultures of aboriginal peoples."206 It was for this reason that the Supreme Court in Delgamuukw placed them at the core of section $91(24) .{ }^{207}$ If rights available only to Indians, and rights that exist only because they

Tsilhqot'in, supra note 1 at para 140 . See also ibid at para 139.

See ibid at paras $142-43$.

Ibid at para 141.

See Sikyea $v$ R, [1964] SCR 642, aff'g [1964] 43 DLR (2d) 150 (NWTCA); $R v$ George, [1966] SCR 267 [George].

Kent McNeil, "Aboriginal Title and the Provinces After Tsilhqot'in Nation" (2015) 71 SCLR (2d) 67 [McNeil, "Aboriginal Title"]. McNeil has argued forcefully, for reasons broadly similar to those set out in this paragraph, that "the Court's rejection of the application of the doctrine of [IJI] cannot have been intended to be retroactive" to a time before section 35 took effect (ibid at 79-80, n 64). "It can also be argued," he adds, "that, right up to the Court's decision in Tsilhqot'in Nation, [IJI] continued to apply to Aboriginal and treaty rights" (ibid). I can live quite happily with that conclusion, but I do not think the Supreme Court's reasoning in Tsilhqot'in compels us to accept it.

See e.g. Dick, supra note 68 at 315; Delgamuukw, supra note 15 at paras $177,181$.

Dick, ibid at 320. See also ibid at 317, 326; Four B Manufacturing Ltd v United Garment Workers of America, [1980] 1 SCR 1031 at 1047-48 [Four B].

Canadian courts have held consistently that international treaties (for example, the Jay Treaty, which does have some specific provisions about Indigenous peoples) are not what the framers had in mind when drafting either section 88 of the Indian Act, supra note 68 (see Francis $v R$, [1956] SCR 618) or section 35 of the Constitution Act, 1982, supra note 6 (see Rv Vincent (1993), 12 OR (3d) 427 (CA)). See e.g. Van der Peet, supra note 144 at para 48.

See Delgamuukw, supra note 15 at para 181. The Supreme Court added that Indigenous peoples' "interest in their lands" is "one of the most central of native interests" and that certain other relationships they have with the land are "equally fundamental to aboriginal peoples" (ibid at para 176). It was principally for these reasons that the Supreme Court held such interests and such relationships to be within exclusive federal authority over "Lands reserved for the Indians" (ibid at para 178). 
are integral to an Indigenous way of life, do not relate to "Indians qua Indians," it is difficult to comprehend what does, or what else could. ${ }^{208}$

But let that go. What would follow from the conclusion that these rights were never at the core of section $91(24)$ ?

The matters located at the core of a head of federal authority comprise the "basic, minimum and unassailable content" 209 of that authority, which makes "Indians" and "Lands reserved for the Indians," for example, "specifically of federal jurisdiction." 210 The core is the exclusive part of federal legislative authority. As such, it is not just a staging ground from which to enforce IJI; it identifies the matters the provinces may not seek to govern. To say that some matter lies outside the core of a head of federal power is not necessarily to say that it lies beyond the reach of federal authority; it is, however, to say that it lies within the reach of provincial legislative authority.

So if treaty and Aboriginal rights lay outside the core of section 91(24) — if, as Tsilhqot'in suggests, jurisdiction over matters relating to them were to be concurrent ${ }^{211}$ then such rights, as such, would be no less susceptible to provincial than to federal legislation. In the absence of valid, conflicting federal law, a province could, in principle, use its own legislative authority ${ }^{212}$ to achieve locally in respect of such rights any result that the federal order could achieve nationwide in respect of them. On these assumptions, it need

Some argue that neither Aboriginal nor treaty rights deserve a place in the core of "Indianness" under section 91(24) because not all Indigenous peoples, or even all First Nations, have either Aboriginal rights or treaty rights, and because the Aboriginal and treaty rights that such peoples do have differ in content from one community to the next. The fact that some ancestral practice was integral to the way of life of some particular Indigenous community, for example, does not mean (this argument runs) that it is characteristic of generic Indianness. Acceptance of this view appears to entail that nothing belongs at the core of section 91(24) unless it is true of all Indians (or of all lands reserved for them) universally. But that is selective, revisionist jurisprudence. As recently as Canadian Western Bank, supra note 11, for example, the Supreme Court has confirmed that "relationships within Indian families and reserve communities" belong within the core of exclusive federal authority because they are "matters that could be considered absolutely indispensable and essential to their cultural survival" (ibid at para 61). But "relationships within Indian families and reserve communities" differ among Indigenous communities. Different nations have different clan structures with different degrees of importance to their members. They also have different internal governance structures, even under the relevant federal legislation (the Indian Act, supra note 68 and the First Nations Elections Act, SC 2014, c 5). Similarly, matters relating to Indian status are known to come within the core of section 91(24) (see Four B, supra note 204 at 1047-48), but there are several different grounds on which to qualify for Indian status (see Indian Act, ibid, ss 6-7, as amended) and different individuals qualify, or fail to qualify, as statutory Indians in different ways, for different reasons. No one, to my knowledge, has successfully argued that the differentiation that exists among Indigenous groups with respect to existing Aboriginal or treaty rights is qualitatively dissimilar to that which exists among Indian status holders or Indian family or governance relationships. This phrase first appears in Bell Canada (1988), supra note 55 at 839.

Ibid at 762 .

Tsilhqot'in, supra note 1 at para 129.

Plausible candidate heads of provincial authority include: "Direct Taxation within the Province" (Constitution Act, 1867, supra note 16, s 92(2)); "The Management and Sale of the Public Lands belonging to the Province and of the Timber and Wood thereon" (ibid, s 92(5)); "Property and Civil Rights in the Province" (ibid, s 92(13)); "The Administration of Justice in the Province" (ibid, s 92(14)); "Generally all Matters of a merely local or private Nature in the Province" (ibid, s 92(16)); and "development, conservation and management of non-renewable natural resources and forestry resources in the province" (ibid, s 92A(1)(b)). 
make no difference whether such rights just happened to come within the catchment of a provincial law of general application or were themselves the focus of the measure. ${ }^{213}$

From this and the "never" hypothesis, it follows, at a minimum, that the provinces could have regulated or constrained treaty and Aboriginal rights almost at will before section 35 took effect in $1982 .{ }^{214}$ But more importantly, it seems to follow that Delgamuukw ${ }^{215}$ was wrong to hold that provinces never had constitutional authority to extinguish them. ${ }^{216}$ According to Delgamuukw, "the only laws with the sufficiently clear and plain intention to extinguish aboriginal rights would be laws in relation to Indians and Indian lands. As a result, a provincial law could never, proprio vigore, extinguish aboriginal rights, because the intention to do so would take the law outside provincial jurisdiction. ${ }^{217}$ But this holds only if Aboriginal rights belong within the core of exclusive federal legislative authority. If they do not, then laws that target, or even extinguish, them are not necessarily laws "in relation to Indians and Indian lands." This conclusion entails that such rights have always been at the mercy of provincial authority, ${ }^{218}$ subject only, today, to the effect of section $35 .^{219}$

Such a result would change profoundly the shape and size of the playing field upon which provincial and Indigenous parties - and, for that matter, Indigenous and non-Indigenous parties - contested about events that occurred before 17 April 1982. It would mean excusing provincial Crowns, and others who had found Indigenous rights and claims an impediment, almost entirely from division of powers challenges to those pre-existing arrangements. But this would make Tsilhqot'in a very expensive decision for Canada's Indigenous peoples,

Kent McNeil disagreed with a previous version of this paragraph. The Constitution, he argued, still prohibits provincial legislation from "singl[ing] out" Indians (see e.g. Four B, supra note 204 at $1048-49 ; R \vee$ Sutherland, [1980] 2 SCR 451 at 455-56; Kitkatla, supra note 25 at para 67) even in respect of matters deemed not to be in the core of exclusive federal authority under section 91(24). It is generally unwise to disagree with McNeil; I would be perfectly happy if he were right and I wrong about this. But we know that provincial laws can be valid despite targeting exclusively entities that come within federal legislative authority; Bank of Toronto v Lambe (1887), 12 AC 575 (PC) (provincial tax aimed only at banks still valid) is perhaps the best-known example. So if treaty and Aboriginal rights really are subject to concurrent, not exclusively federal, legislative authority, I am not sure what doctrinal basis there is for contesting the possibility that provincial legislation focused specifically on them can be valid.

214 This would be true of treaty rights despite section 88 of the Indian Act, supra note 68 , because section 88 pertains exclusively to provincial laws of general application that cannot, because of IJI, apply to Indians as provincial law (see supra note 68). It would follow, therefore, that White and Bob, supra note 66; Simon, supra note 69; and R v Sioui, [1990] 1 SCR 1025 [Sioui], were all wrongly decided. Supra note 15 at paras $172-83$.

216 There is, of course, a difference between having the capacity to extinguish Aboriginal rights and succeeding at extinguishing them. The test for achieving extinguishment - displaying a sufficiently "clear and plain" intention to extinguish - remains, as far as we know, unchanged (see Sparrow, supra note 14 at 1095-99; Gladstone, supra note 15 at paras 31-38). Allegations that a provincial measure extinguished an Aboriginal right would, like comparable allegations involving federal measures, require case by case consideration.

217 Supra note 15 at para 180. See McNeil, "Aboriginal Title," supra note 202 at 82-84, 88. McNeil cites this proposition, and the fact that the Supreme Court in Tsilhqot'in, supra note 1, did not challenge or comment on it, as reason to maintain, despite Tsilhqot'in, that Delgamuukw is still good law on provincial incapacity to extinguish Aboriginal rights before 1982.

218 Imagine, for instance, a provincial statute that expressly extinguished all interests except fee simple interests in lands within the province, or that deemed fee simple Crown patents to extinguish all preexisting interests in the lands to which they pertained. Would it make any difference, assuming that Aboriginal rights are not core federal matters, whether such legislation, for greater certainty, included Aboriginal title in a list of the kinds of interests extinguished?

Section 35 now precludes either order of government from extinguishing Aboriginal rights unilaterally: Van der Peet, supra note 144 at para 28; Mitchell v MNR, 2001 SCC 33, [2001] 1 SCR 911 at para 11. There is, to my knowledge, no law yet on whether section 35 also precludes unilateral extinguishment of treaty rights, but it would be astonishing if it did not. Consider the perverse incentives that would result from such a conclusion. 
exposing their claims of rights and title to a spectre of vulnerability thought to have been definitively laid to rest two decades ago. And it could prove to cheapen substantially the value of the constitutional protection section 35 offers today.

Is this the world the Supreme Court had in mind when it opened section 35 rights to provincial legislative authority? One hopes it would not sever without forethought or acknowledgment a thread of constitutional jurisprudence widely considered settled and reliable. Such hope gives us reason to consider the other hypothesis about the reasoning in Tsilhqot'in - the supposition that section 35's enactment evicted the rights it protects from the core of exclusive federal authority.

\section{B. THE EVICTION HYPOTHESIS}

On this alternative reading, Delgamuukw was correct to hold that provinces never could extinguish Aboriginal rights. ${ }^{220}$ Until the Constitution Act, 1982 came along, such rights were indeed at the core of section 91(24), so Delgamuukw's arguments against provincial extinguishment were, and are, sound. It followed, too, that IJI originally protected treaty and Aboriginal rights altogether from provincial impairment. ${ }^{221}$ Section 35 , once in force, ensured that there could be no subsequent extinguishment of such rights. ${ }^{222}$ But now that we have section 35, this argument continues, it is no longer necessary, and it seems perverse and inconvenient, to preclude the provinces from infringing these rights justifiably. Section 35, in other words, facilitated the eviction of treaty and Aboriginal rights from the core of exclusive federal authority.

This view entails acceptance that section 35's enactment gave provinces significant new authority to constrain the exercise of treaty and Aboriginal rights. That seems an adventurous inference from constitutional text that speaks only of "recogniz[ing] and affirm[ing]" such rights. ${ }^{223}$ Can it possibly be correct?

There is precedent for such reasoning. In R. v. Horseman, ${ }^{224}$ the Supreme Court considered the impact of paragraph 12 of the Alberta Natural Resources Transfer Agreement (NRTA) ${ }^{225}$ on the commercial harvesting rights preserved ${ }^{226}$ in Treaty $8 .{ }^{227}$ Paragraph 12 deems "the laws respecting game in force in the Province" to govern the Indians within the province, subject to the Indians' right "of hunting, trapping and fishing game and fish for food at all seasons of the year on all unoccupied Crown lands and on any other lands to which [they] may have a right of access." 228 The majority held that paragraph 12 extinguished the commercial harvesting right. By way of explanation, it said there was "a quid pro quo granted by the Crown for the reduction in the hunting right. Although the [NRTA] did take

\footnotetext{
$220 \quad$ Supra note 15 at paras 172-83.

221 This, again, is McNeil's preferred interpretation of Tsilhqot'in. See supra notes 202, 217 and the references cited therein.

See supra note 219.

Constitution Act, 1982, supra note 6, s 35(1).

[1990] 1 SCR 901 [Horseman].

Schedule (2) to the Constitution Act, 1930, (20-21 Geo V), c 26 (UK) [NRTA].

See Horseman, supra note 224 at 928-29.

Treaty No 8 Made June 21, 1899, online: <www.aadnc-aandc.gc.ca/eng/1100100028813/11001000 28853>.

NRTA, supra note 225 at para 12.
} 
away the right to hunt commercially, the nature of the right to hunt for food was substantially enlarged." 229 One could argue, by analogy, that section 35 bespeaks a similar quid pro quo, expanding provincial authority to regulate the relevant rights, while limiting federal capacity to do so.

The Horseman panel, however, reached its conclusion with some misgivings. It admitted that "it might well be politically and morally unacceptable in today's climate" — the Supreme Court wrote this in 1990 — "to take such a step as that set out in the 1930 Agreement without consultation with and concurrence of the Native peoples affected." 230 The Constitution Act, 1982 surely is a child of "today's climate," yet there is no indication that Canada's Indigenous peoples were consulted about, let alone that they concurred with, a constitutional quid pro quo that would augment provincial capacity to infringe their treaty or Aboriginal rights. ${ }^{231}$ Construing section 35 as having imposed some such arrangement would, therefore, according to Horseman, invite political and moral censure difficult to reconcile with Sparrow's subsequent direction that section 35 receive "a generous, liberal interpretation" consistent with the honour of the Crown. ${ }^{232}$

In fairness, nothing in the Constitution Act, 1982 precludes adoption of the eviction hypothesis. Part I of the Act, the Charter, says explicitly that it does not "[extend] the legislative powers of any body or authority"; 233 Part II, which houses section 35 , does not. But the Supreme Court has felt free to invoke the Charter by analogy when discussing treaty and Aboriginal rights. It did so in Sparrow, when it imported into section 35 a justification requirement recalling section 1 of the Charter, ${ }^{234}$ and in Tsilhqot'in, which described Parts I and II as "sister provisions" while urging the absurdity of using IJI to protect such rights. ${ }^{235}$ Having relied so heavily on the Charter analogy in explicating section 35, and having insisted elsewhere that "the 1982 amendments [to the Constitution] did not alter the basic division of powers in ss. 91 and 92 of the Constitution Act, 1867,"236 the Supreme Court cannot now credibly insist that Part II modified the division of powers when we know Part I did not.

But the Constitution Act, 1982 did amend the division of powers. Section 50 added a new provision - section $92 \mathrm{~A}$ - to the Constitution Act, 1867, conferring new powers on the provinces, some exclusive, ${ }^{237}$ and some concurrent, ${ }^{238}$ in relation to non-renewable and

Horseman, supra note 224 at 933. The enlargement of the food harvesting right comprised expansion of "[t]he geographical areas in which the Indian people could hunt" and removal from Alberta's jurisdiction of "the means employed by them in hunting for their food" (ibid). See also ibid at 934.

Ibid at 934, Cory J, for the majority. Justice Wilson, who wrote in dissent for three of seven judges, would have held that paragraph 12 had no such effect on Treaty 8 commercial harvesting rights.

They were, after all, sufficiently concerned about the Constitution Act, 1982 to ask the English Courts to prevent its implementation. See $R v$ Secretary of State for Foreign and Commonwealth Affairs, Ex parte Indian Association of Alberta, [1982] 1 QB 892 (CA), aff'd [1982] 1 QB 937 (HL).

Sparrow, supra note 14 at $1106-108$.

Charter, supra note 23, s 31.

Sparrow, supra note 14 at 1108-109.

See Tsilhqot'in, supra note 1 at para 142.

Quebec Secession Reference, supra note 17 at para 47. The Supreme Court described sections 91 and 92 of the Constitution Act, 1867 as "the primary textual expression of the principle of federalism in our Constitution, agreed upon at Confederation" (ibid). See also Morris, supra note 71 ("[t]his justification analysis [under section 35] does not alter the division of powers" at para 55).

See Constitution Act, 1867, supra note 16, s 92A(1).

Ibid, ss 92A(2)-(4). 
forestry resources within their boundaries. This shows that the framers of the Constitution Act, 1982 turned their minds to division of powers issues and used clear language to indicate that, and precisely how, they intended to expand provincial legislative authority. The Constitution Act, 1982 says nothing about expanding provincial capacity in respect of existing Aboriginal or treaty rights. All it does is recognize and affirm them.

Finally, the Supreme Court itself reminded us in 2008 that "the evolution of society cannot serve as a pretext for changing the nature of the division of powers, which is a fundamental component of the Canadian federal system."239 Nothing, therefore, in the constitutional jurisprudence before Tsilhqot'in supports the eviction hypothesis. If Tsilhqot'in is saying that section 35 has evicted treaty and Aboriginal rights from the core of section 91(24), it departs dramatically and without explanation from the previous law.

\section{Either WaY}

There are, again, two ways in which we can understand the argument about IJI in Tsilhqot'in and Grassy Narrows. ${ }^{240}$ It may signify that treaty and Aboriginal rights were never within the core of section 91(24). That would mean abandoning the Supreme Court's conclusion in Delgamuukw ${ }^{241}$ that provinces never had the power to extinguish Aboriginal (or probably treaty) rights, and rethinking what we thought we knew about provincial capacity to regulate and constrain such rights before 1982. Or it may signify that such rights ceased to be within the core of exclusive federal authority only in 1982, when, and because, section 35 took effect. This approach avoids the radical consequences of its alternative, but resists the relevant constitutional text and flouts the Supreme Court's other jurisprudence on the relationship between the division of powers and the 1982 Act. And it would be, if accepted, another instance in which the Crown had used its constitutional leverage to impose on Indigenous peoples, again without their consent, a morally contentious quid pro quo as the price of recognizing and affirming their rights.

Neither of these options is especially appealing. That in itself is disconcerting enough. But other unwelcome consequences emerge no matter which way we construe the Supreme Court's discussions of IJI in Tsilhqot'in and Grassy Narrows.

The Supreme Court has not said that section 91(24) has no core at all; as recently as Daniels, it alluded (albeit backhandedly) to "the core of the 'Indian' power." 242 All it has said is that Aboriginal rights (in Tsilhqot'in) and treaty rights (in Grassy Narrows) are not, or are no longer, within that core. In previous decisions, it had held that the core of exclusive federal authority over "Indians" includes matters relating to "their Indian character or their Indian identity and relationship," 243 including some power to define the term "Indian" "by

Tsilhqot'in, supra note 1 at paras 128-52; Grassy Narrows, supra note 3 at para 53.

Delgamuukw, supra note 15 at paras 172-83.

Daniels, supra note 30 at para 51.

Natural Parents, supra note 55 at 763, Laskin CJC, quoted with approval in Bell Canada (1988), supra note 55 at 836 . 
using criteria suited to this purpose," ${ }^{244}$ Indian status, ${ }^{245}$ "rights so closely connected with Indian status that they should be regarded as necessary incidents of status such for instance as registrability, membership in a band, the right to participate in the election of Chiefs and Band Councils, reserve privileges, etc.,"246 and "relationships within Indian families and reserve communities." 247 It is, again, unlikely that any of these matters has a better substantive claim for inclusion in the "core of Indianness"248 than rights set out in agreements negotiated exclusively with Indians and available only to them, or rights defined with reference to what is integral to their distinctive ways of life. ${ }^{249}$ But we must assume, until further notice, that the core of the "Indians" power still comprises at least these matters.

There is, however, considerable room for overlap between many of them and the potential subject matter of Aboriginal rights. We know, for example, that marriage customs can be Aboriginal rights, ${ }^{250}$ and that the Stellaquo Carrier peoples have an Aboriginal right to define their parental relationships. ${ }^{251}$ But matters involving Indian marriage and parental status surely also qualify, for purposes of "core of Indianness" jurisprudence, as "relationships within Indian families and reserve communities." ${ }^{252}$ Who gets to decide, in a given instance, whether to treat some such matter in one way or the other? Is a finding, or the mere possibility of a finding, that a given custom, tradition, or practice is an Aboriginal right fatal to its eligibility for IJI protection, even when, viewed differently, it would lie well within the protected "core of Indianness"? If so, the law gives Indigenous communities interested in protecting their parental customs, for instance, from provincial regulation perverse incentives not to assert those customs as Aboriginal rights, and gives provincial Crowns perverse contrary incentives when they believe they can justify their regulatory schemes. But if not, then claimant communities will often be able to shield behind IJI despite already having proven certain Aboriginal rights by choosing selectively not to rely on those rights, but on their Indianness.

We fare no better with the core of the federal power over "Lands reserved for the Indians." Tsilhqot'in insists that that core no longer includes (if it ever did) Aboriginal title. But we know from previous jurisprudence, some of it very recent, ${ }^{253}$ that the core of that power does

Canada (AG) v Canard, [1976] 1 SCR 170 at 207, Beetz J.

Natural Parents, supra note 55 at 760-61, Laskin CJC; at 787, Beetz J; Four B, supra note 204 at 1047; NIL/TU,O Child and Family Services Society v BC Government and Service Employees’ Union, 2010 SCC 45, [2010] 2 SCR 696 at para 71 [NIL/TU,O], McLachlin CJC and Fish J, concurring.

Four B, ibid at 1048; NIL/TU,O, ibid at para 71, McLachlin CJC and Fish J, concurring. Cf NIL/TU,O, ibid at para 70: "the core, or 'basic, minimum and unassailable content' of the federal power over 'Indians' in s. 91(24) is defined as matters that go to the status and rights of Indians."

Canadian Western Bank, supra note 11 at para 61. The Supreme Court observed that these are "matters that could be considered absolutely indispensable and essential to their cultural survival" (ibid); NIL/TU,O, ibid at para 71. Cf Natural Parents, supra note 55 at 761, Laskin CJC.

Dick, supra note 68 at 315; Delgamuukw, supra note 15 at paras $177-81$.

See supra notes 203-208 and accompanying text.

See Manychief, supra note 145.

Casimel v Insurance Corp of British Columbia (1993), 106 DLR (4th) 720 (BCCA).

Canadian Western Bank, supra note 11 at para 61, quoted in the text above at note 247 .

In Sechelt Indian Band v British Columbia (Manufactured Home Park Tenancy Act, Dispute Resolution Officer), 2013 BCCA 262, [2013] 9 WWR 274, the British Columbia Court of Appeal held that IJI rendered provincial mobile home park legislation inapplicable to Sechelt fee simple (!) lands deemed by federal legislation to be "lands reserved for the Indians." On 23 October 2014, four months after its decision in Tsilhqot'in, supra note 1, the Supreme Court dismissed, with costs, the province's application for leave to appeal: see Supreme Court of Canada, "Bulletin of Proceedings" (24 October 2014), online: <https://scc-csc.lexum.com/scc-csc/ bulletins/en/item/4732/index.do>. 
include matters relating to possession, occupation, and disposition, ${ }^{254}$ and presumably also to use, ${ }^{255}$ of reserve lands. This discrepancy leaves reserve lands better protected than Aboriginal title lands from provincial legislative interference, undoing the functional equivalence the Supreme Court and the Privy Council established among Indigenous interests in the various "Lands reserved for the Indians." 256

But now even some reserve lands are more functionally equivalent than others. Many reserves in Canada exist pursuant to treaty, but not all do. Some reserves, especially, though not exclusively, in British Columbia, came into being administratively, as a result of unilateral Crown activity. ${ }^{257}$ Where reserves derive from treaty, the Aboriginal interest in them is a treaty right. Treaty rights, according to Grassy Narrows, are subject to justified provincial infringement. ${ }^{258}$ But where does this leave matters relating to the possession, occupation, disposition, or use of treaty reserve lands? Are they still within the exclusive core of section 91(24) in accordance with earlier authority? Or are section 35 and the federal paramountcy doctrine now the only constitutional standards against which to test provincial capacity to control such matters? If the former, then treaty rights to reserve land will, despite Grassy Narrows, continue to benefit from IJI as long as they relate to matters within the core of federal power over "Lands reserved for the Indians." But if the latter, then interests in reserve land that derive exclusively from Crown fiat (or whim) have, and retain, greater protection from provincial land law than those that now have the status of constitutional rights. Either response leaves ample scope for perverse negotiation incentives.

Finally, please spare a thought for section 88 of the Indian Act. ${ }^{259}$ "Section 88," the Supreme Court held unanimously in 1990, "is designed specifically to protect the Indians from provincial legislation that might attempt to deprive them of rights protected by a treaty." 260 This conclusion comports with what little we know of section 88 's provenance. ${ }^{261}$

254 Derrickson, supra note 68 at 296; Paul v Paul, [1986] 1 SCR 306; NIL/TU,O, supra note 245 at para 71, McLachlin CJC and Fish J, concurring.

255 Derrickson, ibid at 295, quoting with approval Lysyk, supra note 102 at 227, n 49.

256 See supra note 101 and accompanying text.

257 For examples of reserves created by unilateral Crown activity, see Wewaykum Indian Band v Canada, 2002 SCC 79, [2002] 4 SCR 245.

$258 \quad$ Supra note 3 at para 53.

259 Indian Act, supra note 68. Section 88 reads as follows:

Subject to the terms of any treaty and any other Act of Parliament, all laws of general application from time to time in force in any province are applicable to and in respect of Indians in the province, except to the extent that those laws are inconsistent with this Act or the First Nations Fiscal Management Act, or with any order, rule, regulation or law of a band made under those Acts, and except to the extent that those provincial laws make provision for any matter for which provision is made by or under those Acts.

260 Sioui, supra note 214 at 1065 . See also George, supra note 201 at 281.

261 At a meeting held in early 1951 to discuss the pending bill that introduced section 87 (now 88 ), the federal government assured the Indigenous representatives in attendance that "provincial laws would not apply if they contravened any treaty, and/or any act of parliament" (House of Commons Debates, 21 st Parl, 4th Sess, vol 2 (16 March 1951) at 1367). In testimony before the Special House of Commons Committee appointed to consider the bill, the Minister responsible for the bill, the Honourable Walter Harris, assured the Committee that what was then section 87 (now 88) "does not affect their treaty rights at all": House of Commons, Special Committee Appointed to Consider Bill No 79: An Act Respecting Indians, Minutes of Proceedings and Evidence, No 1 (April 1951) at 168. House of Commons debates dealt with treaty rights issues and their relationship to provincial law on several occasions during deliberations over the 1950 and 1951 Indian Act revisions: see House of Commons Debates, 21st Parl, 2nd Sess, vol 1 (21 March 1950) at 957-59, vol 4 (21 June 1950) at 3943, 3964-65; House of Commons Debates, 21st Parl, 4th Sess, vol 1 (27 February 1951) at 715-16, 757, vol 2 (16 March 1951) at 1351-52, vol 4 (15 May 1951) at 3048-49. I discuss section 88's legislative history at some length in Kerry Wilkins, "'Still Crazy After All These Years': Section 88 of the Indian Act at Fifty" (2000) 38:2 Alta L Rev 458 at 460-65, 501 [Wilkins, "Still Crazy"]. 
But the Supreme Court has also insisted that section 88 governs only those valid provincial laws of general application that IJI precludes from applying to Indians as provincial law. ${ }^{262}$ In the past, this conclusion did not compromise the protection treaty rights derived from section 88 because the courts had always placed such rights within the core of exclusive federal legislative authority. ${ }^{263}$ But when Grassy Narrows banished treaty rights as such from that core, it effectively exempted from section 88 's operation provincial laws that infringe or impair such rights. Now that provincial laws may apply and infringe treaty rights of their own force, section 88 affords them no protection.

Does section 88 have any meaningful work left to do in the wake of Tsilhqot'in and Grassy Narrows? ${ }^{264}$ We do not know. Even before these two decisions, section 88 lay dormant, like Jack pine cones awaiting a forest fire, until a court used IJI to render a valid provincial law inapplicable to statutory Indians. Only then did it give the provincial law extended reach as federal law, subject to the exceptions and restrictions section 88 includes. Such relevance as section 88 continues to have will depend on what remains at the core of exclusive federal authority over "Indians." That, in turn, will depend in part on what we say about the status of matters still (as far as we know) within that core that also happen to be the subjects of possible treaty or Aboriginal rights. ${ }^{265}$

\section{RECKONING}

Few issues in contemporary Canadian constitutional law are as difficult, or as important to get right, as the relationship between the provinces and Indigenous peoples. Neither the provinces nor Indigenous peoples are going anywhere anytime soon, so ongoing interactions between them are all but inevitable. Is it better to prohibit provinces outright from implementing and enforcing mandatory measures that limit treaty and Aboriginal rights and their exercise, or to countenance and supervise some such provincial control, subject to a justification requirement? The question is made more difficult when we still know so little about what Aboriginal rights there are, and about the nature and breadth of the rights treaties provide. Almost certainly, the outcomes of these different inquiries will shape one another, implicitly if not explicitly.

The Supreme Court was astute to recognize the importance of this issue, and courageous to seek to resolve it decisively. The tragedy, or the travesty, is that it so thoroughly underestimated its difficulty. The reasoning it offers in Tsilhqot'in for denying IJI protection to section 35 rights privileges expediency over cogency. It ignores, when it does not mischaracterize, a great deal of previous authority, leaving behind a farrago of confusion about the extent, if any, of provincial legislative authority over treaty and Aboriginal rights before 1982, the relationship between the division of powers and the Constitution Act, 1982, the status of whatever remains at the core of exclusive federal authority under section 91(24), the relevance, if any, of section 88 of the Indian Act, and even the currency of the notion that

264 Some of us had doubts about section 88's usefulness even before the decisions in Tsilhqot'in and Grassy Narrows. For my own misgivings about section 88, see Wilkins, "Still Crazy," supra note 261. See also Kent McNeil, "Aboriginal Title and Section 88 of the Indian Act" (2000) 34:1 UBC L Rev 159. 
at least some federal and provincial powers are still exclusive. It is hard to believe the Supreme Court even noticed how thoroughly it was disrupting accepted constitutional doctrine. Such argumentation taints its conclusion with arbitrariness.

Yet the most that follows from this critique is that the Supreme Court's conclusion about section 35 rights and IJI is unsubstantiated; it does not follow that it got the answer wrong. It is possible that its underlying intuition was sound. Involving provinces meaningfully in the conversation about the responsible exercise of section 35 rights has some distinct potential advantages. It might well mitigate their often reflexive opposition to efforts to establish or use such rights; it might create opportunities for productive cooperation that could not arise if the law left provinces powerless in respect of such rights. At a minimum, it has potential to lower the temperature during discussions, in court or outside, about these rights and their scope, and to dispose courts more favourably toward accrediting meaningful Aboriginal rights.

I am open to the possibility that the Supreme Court was correct to exclude section 35 rights from IJI, but I am not yet convinced that it was. Even entertaining that possibility, however, requires that we acknowledge and take responsibility for its full doctrinal cost. The hard truth is that the jurisprudential framework we have inherited does not readily accommodate even justified provincial infringement of such rights. If we wish nonetheless to embrace provincial capacity to infringe them, we must, in the interest of preserving coherence within that framework, agree to abandon one or more of its familiar features with which such capacity is in tension, and to tolerate such renewed doctrinal uncertainty and realignment as must necessarily result. Revisions of this magnitude are, in principle, always possible. But we are wise to undertake them in full knowledge of what they involve and in the confidence that the circumstances warrant the revision.

What might we consider discarding for this purpose?

We could discard the idea that the enumerated heads of provincial and federal legislative authority each have "cores" of exclusive content. But that would mean abandoning the organizing principle of Canadian federalism: the notion that each order of government has, for good reason, all and only the powers it has, and that it really does matter which order of government does what. ${ }^{266}$ If none of this authority were exclusive, each could do pretty much whatever it wanted, subject, again, only to the Charter, section 35, a guaranteed core of superior court jurisdiction, and the federal paramountcy rule. ${ }^{267}$ And how, in the absence of meaningful differentiation in their roles and powers, might we continue to justify the expense and the duplication unavoidable with multiple orders of government?

We could decide to dispense with IJI altogether, tolerating accidental, but not advertent or surreptitious, provincial governance over the "matters of national importance" 268 that lie

266 See supra notes 20-21 and accompanying text.

267 On the dangers that concurrent jurisdiction, coupled with federal paramountcy, pose to provincial autonomy, see Bruce Ryder, "Equal Autonomy in Canadian Federalism: The Continuing Search for Balance in the Interpretation of the Division of Powers" (2011) 54 SCLR (2d) 565 at 594-95; Bruce Ryder, "The Demise and Rise of the Classical Paradigm in Canadian Federalism: Promoting Autonomy for the Provinces and First Nations" (1991) 36:2 McGill LJ 308.

See Moloney, supra note 20 at para 14. 
within exclusive federal legislative authority. But if we did, what useful purpose would it serve to continue calling such authority exclusive? The point of assigning exclusive authority over particular matters is to leave one order of government solely in charge of deciding whether, and how, to regulate them. ${ }^{269}$ This is not what happens when core federal matters are subject to valid provincial legislation. And why, exactly, is inadvertent provincial governance of such matters, achieved without regard for what gives them national importance, less objectionable than deliberate provincial governance?

On the other hand, we could abandon the notion that matters relating to "Indians, and Lands reserved for the Indians" are the proper business of the federal order of government exclusively. The rationale offered in Daniels for section $91(24)^{270}$ invites us to wonder whether it still serves any useful constitutional purpose, but even here the Supreme Court insisted that there was "tangible practical utility"271 in determining that the federal, not the provincial, order has legislative authority over the Metis. The better view, I believe, is that section 91(24) bespeaks a determination to insulate Indigenous communities and their lands somewhat from the adversarial pressures of competing local interests. ${ }^{272}$ So understood, it affords ongoing protection to Indigenous peoples additional to that which they derive from the Constitution Act, 1982. Reasonable people, Indigenous and non-, can differ over whether such protection is still appropriate (they may differ too about how much real benefit Indigenous peoples themselves have derived from federal supervision, and from the "jurisdictional tug-of-war" ${ }^{273}$ that has ensued as its result). Any deliberation about its ongoing value, however, must feature prominently the voices of Canada's Indigenous peoples. Terminating exclusive federal legislative authority over "Indians, and Lands reserved for the Indians" would require constitutional amendment. And the Constitution itself now requires that a constitutional conference - one that includes representatives of the Indigenous peoples — precede any amendment affecting section 91(24). ${ }^{274}$

Pending implementation of any of these extraordinary options, certain matters still lie at the core of exclusive federal authority under section 91(24), and therefore, beyond the reach of provincial legislative power. The courts have spoken loosely of "Indianness" - matters, as I would put it, unique to and characteristic of Indians as such - as the criterion of qualification for admission to this core of exclusive authority. The problem, again, is that treaty and Aboriginal rights, given their provenance and their uniqueness, are virtual paradigms of Indianness. It was reasonable for the Supreme Court to conclude, in all those cases before Tsilhqot'in, ${ }^{275}$ that such rights belonged in the core and were eligible for IJI protection. If we are now to exclude such rights from the core of section 91(24), we need a different, defensible way - one that does not seem random or merely convenient - of identifying the matters left to populate that core.

See supra notes 54-60 and accompanying text.

See supra note 40 and accompanying text. Again, I find this rationale unconvincing: see supra notes $42-44$ and accompanying text.

Supra note 30 at para 15.

See supra notes 46-51 and accompanying text.

Daniels, supra note 30 at para 15.

Constitution Act, 1982, supra note 6, s 35.1, added by the Constitutional Amendment Proclamation, 1983, SI/84-102.

See supra notes 66-79 and accompanying text. 
Finally, we could treat the Constitution Act, 1982 (even apart from section 50) ${ }^{276}$ as having reconfigured the division of powers. Unless we repealed or overlooked section 31 of the Charter, however, such reconfiguration would pertain uniquely to section 35 . Vindicating such targeted reconfiguration seems difficult. And even that would not suffice to evict existing treaty or Aboriginal rights from the core of section 91(24); one could as easily say that section 35, as phrased, assured their place there. One would have to insist, in addition, that attaining explicit constitutional recognition and affirmation reduced their national importance enough to disqualify such rights from a place in the core.

There is no easy solution to this predicament; we accomplish nothing useful when we understate its difficulty. Any option we choose - even one that denies provincial capacity to infringe section 35 rights - will cost us, and the constitutional order, something we have good reason to care about.

The optimal outcome in this less than perfect circumstance will be one that results from a national conversation much more extensive than this issue has yet received: a conversation that gives full faith and credit to the voices and views of the Indigenous peoples whose rights, and claims of right, are at stake. We must hope that the Supreme Court's ruminations about this issue in Tsilhqot'in and Grassy Narrows will stimulate that crucial conversation. ${ }^{277}$ It would be mortifying if, instead, they foreclosed it.

277 Recall the Supreme Court's own acknowledgment that it need not have discussed IJI in either Tsilhqot'in, supra note 1, or Grassy Narrows, supra note 3: see supra notes 7-10 and accompanying text. Kent McNeil has suggested that this admission "may have been intended to provide the Supreme Court with flexibility" (McNeil, "Aboriginal Title," supra note 202 at 88). He finds in it grounds for optimism "that in future cases the Court will reconsider problematic aspects of its decision in Tsilhqot'in Nation on the application of provincial laws to Aboriginal title lands" (ibid at 89). On the other hand, the Supreme Court did twice go out of its way to put on the record its views about IJI and section 35 rights. As usual, I hope McNeil is right. Time will tell. 
[this page is intentionally blank] 